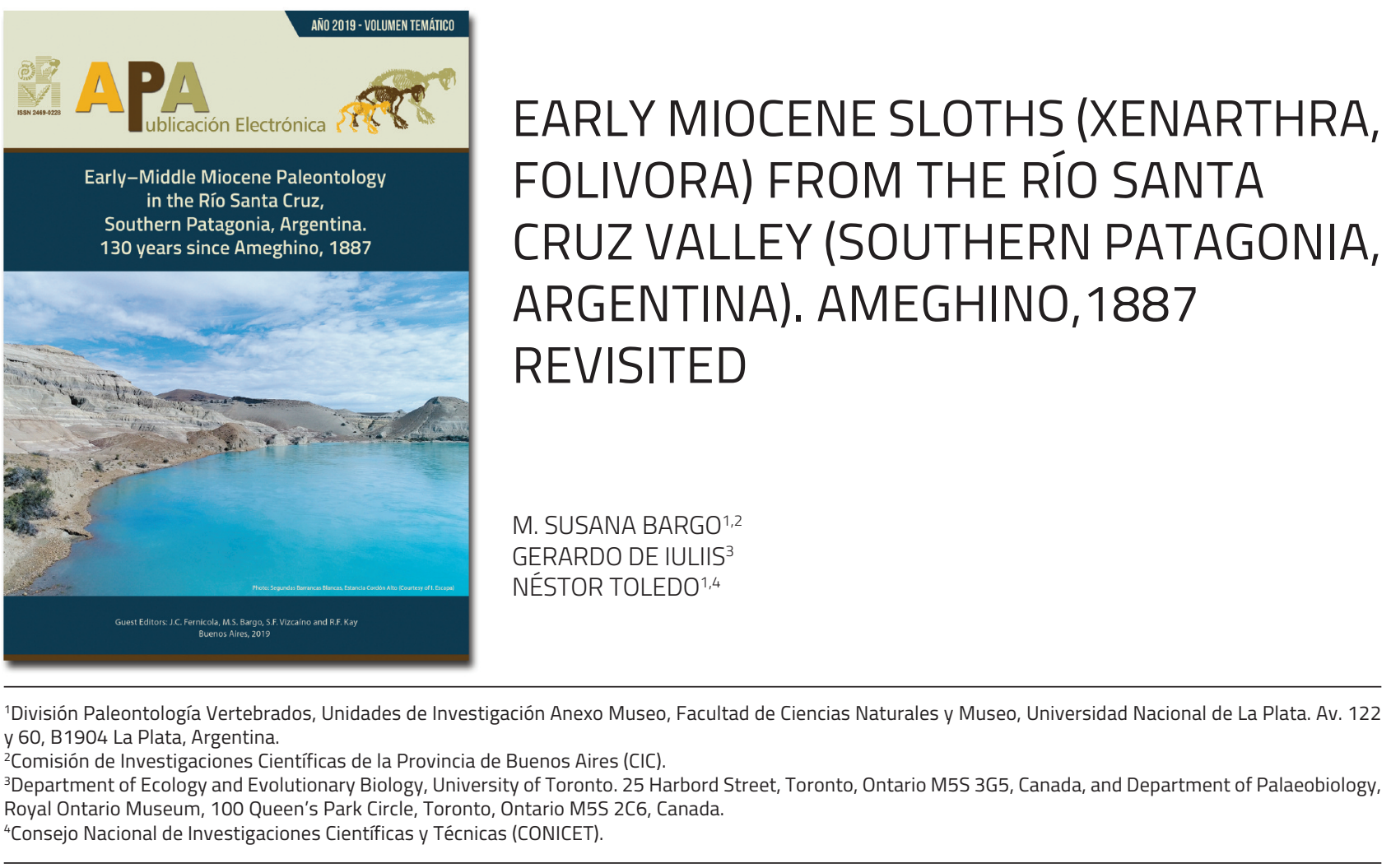

Recibido: 6 de mayo 2019 - Aceptado: 6 de agosto 2019

Para citar este artículo: M. Susana Bargo, Gerardo De luliis, and Néstor Toledo (2019). Early Miocene sloths (Xenarthra, Folivora) from the Río Santa Cruz valley (Southern Patagonia, Argentina). Ameghino, 1887 revisited. Publicación Electrónica de la Asociación Paleontológica Argentina 19 (2): 102-137.

Link a este artículo: http://dx.doi.org/10.5710/PEAPA.06.08.2019.297

DESPLAZARSE HACIA ABAJO PARA ACCEDER AL ARTÍCULO

Asociación Paleontológica Argentina Maipú $6451^{\circ}$ piso, C1006ACG, Buenos Aires República Argentina Tel/Fax (54-11) 4326-7563

Otros artículos en Publicación Electrónica de la APA 19(2): Web: www.apaleontologica.org.ar

\section{P. Muzzopappa}

CALYPTOCEPHALELLA (ANURA, AUSTRALOBATRACHIA) REMAINS FROM RÍO SANTA CRUZ (EARLY-MIDDLE MIOCENE, SANTA CRUZ FORMATION), SANTA CRUZ PROVINCE, ARGENTINA

\section{Fernández, N.A. Muñoz}

NOTOUNGULATA AND ASTRAPOTHERIA (MAMMALIA, MERIDIUNGULATA) OF THE SANTA CRUZ FORMATION (EARLY-MIDDLE MIOCENE) ALONG THE RÍO SANTA CRUZ, ARGENTINE PATAGONIA

\section{G. Schmidt et al.}

LITOPTERNA (MAMMALIA) FROM THE SANTA CRUZ FORMATION (EARLY-MIDDLE MIOCENE) AT RÍO SANTA CRUZ, SOUTHERN ARGENTINA 


\title{
EARLY MIOCENE SLOTHS (XENARTHRA, FOLIVORA) FROM THE RÍO SANTA CRUZ VALLEY (SOUTHERN PATAGONIA, ARGENTINA). AMEGHINO, 1887 REVISITED
}

\author{
M. SUSANA BARGO1,2, GERARDO DE IULIIS ${ }^{3}$, AND NÉSTOR TOLEDO 1,4
}

${ }^{1}$ División Paleontología Vertebrados, Unidades de Investigación Anexo Museo, Facultad de Ciencias Naturales y Museo, Universidad Nacional de La Plata. Av. 122 y 60, B1904 La Plata, Argentina.msbargo@fcnym.unlp.edu.ar; ntoledo@fcnym.unlp.edu.ar

${ }^{2}$ Comisión de Investigaciones Científicas de la Provincia de Buenos Aires (CIC).

${ }^{3}$ Department of Ecology and Evolutionary Biology, University of Toronto. 25 Harbord Street, Toronto, Ontario M5S 3G5, Canada, and Department of Palaeobiology, Royal Ontario Museum, 100 Queen's Park Circle, Toronto, Ontario M5S 2C6, Canada. gerry.deiuliis@utoronto.ca

${ }^{4}$ Consejo Nacional de Investigaciones Científicas y Técnicas (CONICET).

\begin{abstract}
The first detailed geological and paleontological survey of the Santa Cruz Formation (Early-Middle Miocene; Burdigalian-early Langhian) along the Río Santa Cruz was carried out in 1887 by Carlos Ameghino, who recovered more than 2000 fossil remains. In that same year, his brother Florentino studied and reported these remains, recognizing 122 taxa, of which 110 were new species. Fourteen of these new species were of sloths (Xenarthra, Folivora). In this contribution we report and describe new fossil sloth remains recovered in recent expeditions (between 2013 and 2014) along the southern banks of the Río Santa Cruz. The new specimens were recovered from two localities: Barrancas Blancas and Segundas Barrancas Blancas. We review the taxonomic richness of fossil sloths, in comparison with other Santacrucian localities recently studied, e.g, from the Atlantic coast and from the Andean region. An analysis of the original taxa erected by Ameghino is also included. As several of the original fossils on which these taxa are based are no longer available, we explore the value of the new collection in helping resolve systematic issues, as well as considering the specimens that formed the basis for the species erected by Ameghino in 1887. Further, the degree to which W.B. Scott's systematic decisions on the Santacrucian sloths, published in 1903 and 1904 , should continue to be recognized is also assessed.
\end{abstract}

Key words. Burdigalian. Santacrucian. Phyllophaga. Taxonomy. Holotype. Ameghino.

Resumen. LOS PEREZOSOS (XENARTHRA, FOLIVORA) DEL MIOCENO TEMPRANO DEL VALLE DEL RÍO SANTA CRUZ (PATAGONIA AUSTRAL, ARGENTINA). REEXAMINANDO AMEGHINO, 1887. La primera exploración geológica y paleontológica de la Formación Santa Cruz (Mioceno Temprano-Medio; Burdigaliense-Langhiense temprano) a lo largo del Río Santa Cruz fue llevada a cabo en 1887 por Carlos Ameghino, quien recuperó más de 2.000 restos fósiles. Ese mismo año, su hermano Florentino estudió y reportó estos restos fósiles; reconoció 122 taxones de los cuales 110 eran nuevas especies. De estas últimas, resultaron 14 nuevas especies de perezosos (Xenarthra, Folivora). En esta contribución se reportan y describen nuevos restos fósiles de perezosos recuperados en trabajos de campo recientes (entre 2013 y 2014 ) en la margen sur del Río Santa Cruz. Los nuevos especímenes provienen de dos localidades: Barrancas Blancas y Segundas Barrancas Blancas. Se analizó la riqueza taxonómica del grupo en comparación con otras localidades santacrucenses estudiadas recientemente, e.g., de la costa atlántica y de la región andina. Se incluye además un análisis de los taxones originales erigidos por Ameghino. Debido a que muchos de los especímenes originales sobre los que se han basado estos taxones ya no están disponibles, se analiza la importancia de las nuevas colecciones para resolver cuestiones sistemáticas y se consideran los especímenes sobre los que Ameghino erigió las primeras especies en 1887. Asimismo, se evalúa el grado en que las decisiones sistemáticas sobre perezosos santacrucenses realizadas por W.B. Scott, en 1903 y 1904, deben continuar siendo reconocidas.

Palabras clave. Burdigaliense. Santacrucense. Phyllophaga. Taxonomía. Holotipo. Ameghino.

SLOTHS or Folivora belong to Xenarthra, one of the four major clades of placental mammals, although a consensus on their relationships has not been achieved (see Asher and Helgen, 2010; Meredith et al., 2011; O'Leary et al., 2013; Delsuc et al., 2019; Presslee et al., 2019). The fossil history of sloths is ex- tremely rich and diverse, constituting one of the largest and most distinctive elements of the South American Cenozoic fauna. The long standing consensus on phylogenetic relationships, based on osteological characters, recognizes five main sloth clades (Gaudin, 2004; Pujos et al., 2007; 
Amson et al., 2016): Bradypodidae (the sister clade to all remaining sloths and including only the extant Bradypus), Megalonychidae (including one extant genus, Choloepus, and several extinct genera), Nothrotheriidae, Megatheriidae, and Mylodontidae (with numerous extinct genera; see McDonald and De luliis, 2008 for a review). Megalonychidae, Nothrotheriidae, and Megatheriidae form a monophyletic clade, Megatherioidea (Gaudin, 2004). However, recent molecular based analyses by Delsuc et al. (2019) and Presslee et al. (2019) proposed a marked departure from this arrangement, with Bradypus being closely related to Nothrotheriidae and Megatheriidae (i.e., Megatherioidea) and Choloepus to Mylodontidae. Living sloths are small sized (from $\sim 3$ to $8 \mathrm{~kg}$ ), and almost exclusively arboreal and folivorous. Fossil sloths include a wide range of body sizes (from tens of kg to almost five tons), and a variety of dietary and locomotory habits (e.g., Bargo, 2001; Pujos et al., 2007; Bargo and Vizcaíno, 2008; McDonald and De luliis, 2008; Vizcaíno et al., 2008; Bargo et al., 2009, 2012; Amson et al., 2014).

This contribution focuses on the sloths of the Santa Cruz Formation (SCF; Early-Middle Miocene; Burdigalianearly Langhian) of southern Patagonia, recovered from exposures along the Río Santa Cruz valley (Cuitiño et al., 2019a; Fernicola et al., 2019). The SCF is one of the most relevant stratigraphic units of southern South America in terms of the Miocene terrestrial stratigraphic record, upon which Pascual et al. (1965) based the South American Land Mammal Ages (SALMAs; Vizcaíno et al., 2012a). The SCF is widely distributed in the Austral (= Magallanes) Basin in the Province of Santa Cruz (Argentina). It crops out in the northwest area of the province, the central region along the Río Santa Cruz (Fernicola et al., 2014; Cuitiño et al., 2016) and Chalía (= Sehuen; Vizcaíno et al., 2018), and in the southeastern area along the Atlantic coast (Vizcaíno et al., 2012b). This continental sedimentary unit is composed of mudstones, tuffaceous sandstones, and tuffs deposited in fluvial environments under the influence of intense explosive pyroclastic input (Matheos and Raigemborn, 2012; Raigemborn et al., 2015 and Cuitiño et al., 2016 for extensive geological descriptions). The SCF along the Río Santa Cruz is part of extra-Andean Patagonia and crops out in both margins of the river; the exposed unit below the SCF is the marine Early
Miocene Monte León Formation (Parras et al., 2012). The SCF was recently studied and described in three locations (see below) along the river by Cuitiño et al. (2016; see also Cuitiño et al., 2019a). Radiometric ages for the entire SCF span the interval $\sim 18$ to $15.60 \mathrm{Ma}$, being 18-16 Ma for the Atlantic coastal localities (Perkins et al., 2012; Fleagle et al., 2012); 18.20-15.60 Ma for the Río Bote and Río Santa Cruz localities (Cuitiño et al., 2016), and 18-14 Ma for the Lago Posadas region (Perkins et al., 2012).

The Río Santa Cruz valley was first geographically explored in 1877 by F. P. Moreno (1879). Carlos Ameghino made the first detailed geological and paleontological exploration in 1887 collecting more than 2000 fossil remains. Many of these fossils were promptly studied and reported by his brother Florentino in a concise paper that recognized 122 taxa, 110 of which were new species (Ameghino, 1887). None of the taxa was figured nor were the localities indicated (see Fernicola et al., 2019). In a later contribution, Ameghino (1889) expanded the descriptions of the taxa, upon which he based the Formación Santacruceña and Piso Santacruceño (Santacrucian Stage), and figured many of them (see Fernicola, 2011). Over the subsequent years, more widely exposed and highly fossiliferous outcrops of the SCF, such as those located to the southeast along the Atlantic coast, took such priority in the paleontological literature (see Vizcaíno et al., 2012a and references therein) that C. Ameghino's Río Santa Cruz discoveries were largely forgotten. Recently, Fernicola et al. (2014) provided the precise geographic location of C. Ameghino's (1887) fossiliferous localities, formalized their names, and evaluated the stratigraphic position of the mammal-bearing levels (see Fernicola et al., 2019 for a review of the historical context). The fossil localities prospected by C. Ameghino along the Río Santa Cruz, and recognized by Fernicola et al. (2014) are, from east to west: Barrancas Blancas (= Estancias Santa Lucía and Aguada Grande), Segundas Barrancas Blancas (= Estancias Cordón Alto, El Tordillo, and Rincón Grande), and Yaten Huageno (= Estancia El Refugio) (Fig. 1). C. Ameghino also prospected in the nearby area of Lago Argentino in a fourth locality named Río Bote (= Estancia María Elisa).

The goal of this contribution is to describe new sloth remains recently recovered from fossiliferous localities along the Río Santa Cruz, and to review the taxonomic richness of 


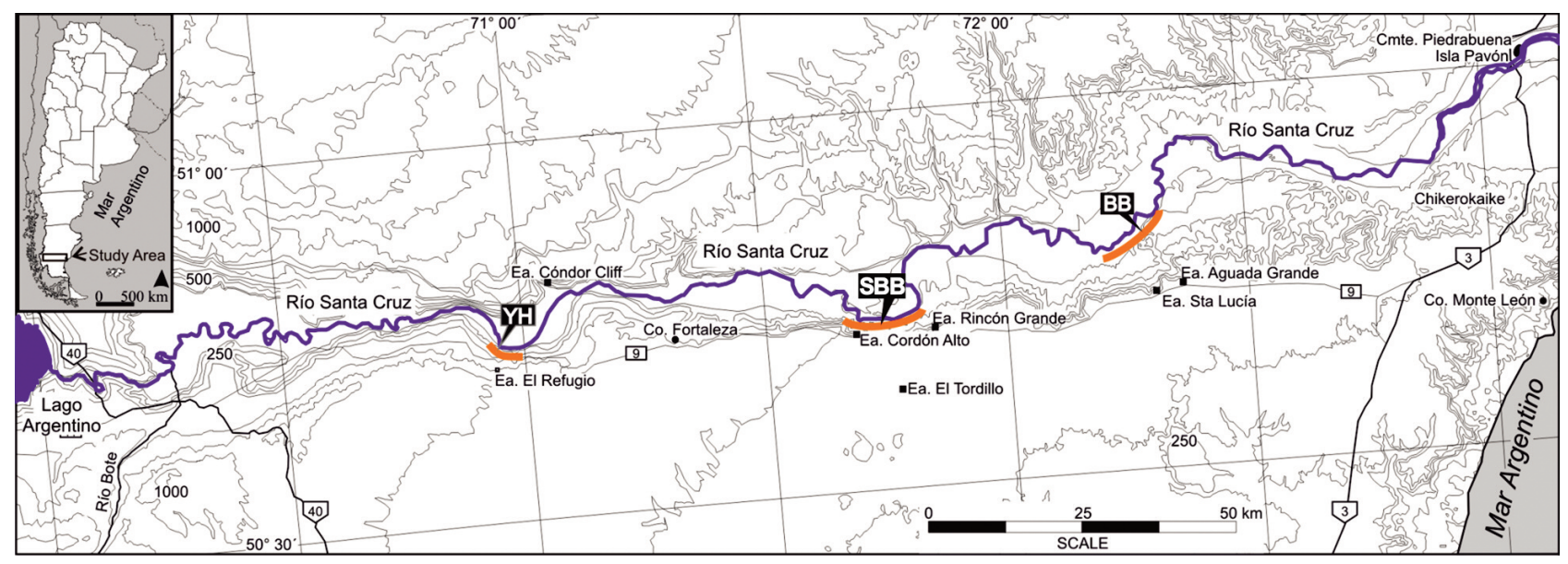

Figure 1. Map of the Río Santa Cruz indicating the prospected localities and estancias mentioned in the text. SBB, Segundas Barrancas Blancas; BB, Barrancas Blancas; Co., Cerro; Ea., Estancia; YH, Yaten Huageno. Modified from Fernicola et al. (2014).

sloths in comparison with other Santacrucian localities. A review of the original taxa of the Río Santa Cruz erected by Ameghino (1887) is also included.

\section{TAXONOMIC AND PHYLOGENETIC BACKGROUND}

Our current understanding of the systematics of the Santacrucian sloths (but see below for Eucholoeops Ameghino, 1887 and Schismotherium Ameghino, 1887) is based mainly on the work of Ameghino (e.g., 1887, 1891a, 1894), as interpreted and revised by Scott $(1903,1904)$. Indeed, our concept of these sloths has remained largely static since Scott's efforts more than a century ago, and it has long been appreciated that they are in dire need of revision (see De Iuliis et al., 2014). Although Scott's efforts clarified aspects of F. Ameghino's work, there remained a good deal of ambiguity over Santacrucian sloth systematics: the number of valid species and genera, what precisely they represent, how they are distinguished from each other, and the lowerlevel relationships among them remain as uncertain as when Scott last dealt with them. As noted in De luliis et al. (2014; see also McDonald and De luliis, 2008), the numerous taxa erected by earlier workers (e.g., Ameghino 1887, 1891a, 1894, 1897; Mercerat, 1891; Lydekker, 1894) were based largely on fragmentary remains, and there are many more published taxa than can be justified on the available material.

Scott's $(1903,1904)$ extensive work attempted to synthesize the then known material and reconcile it with the taxonomic impasse that had developed, due mainly to the multiplication of taxa largely through Ameghino's (e.g., 1887, 1891a, 1894) creation of new species and genera based often on inadequate material. De luliis et al. (2014) outlined this situation with regard to Eucholoeops, but it is also true for other taxa, particularly Hapalops Ameghino, 1887: even Scott's attempts could not resolve the taxonomic situation, with this author admitting that the 22 Hapalops species that he recognized (reduced from the many more named mainly by F. Ameghino) were probably too many (Scott, 1904, p. 261), despite the fact that this list includes, ironically, several new Hapalops species that Scott himself erected. In addition to the 22 species that Scott $(1903,1904$, p. 258) considered "as more or less well defined", he listed another 15 for which he "could arrive at no definite conclusion".

Nevertheless, making headway into resolving taxonomic issues must begin with consideration, as much as possible, of the original specimens, and the work of Scott, who is considered first reviser of Ameghino's work (see De luliis et al., 2014). Scott was the only researcher who examined (during his visit to Argentina in 1901; Vizcaíno et al., 2017) nearly all the material that had entered into the decisions by $F$. Ameghino, A. Mercerat, and R. Lydekker, and he also had access to considerable new material resulting from expeditions to Patagonia by Princeton University (the Princeton Material, except for a composite mounted skeleton, is currently housed in Yale's Peabody Museum, New Haven, 
USA) and the American Museum of Natural History (New York, USA). As noted below, however, strict adherence to Scott's decisions is among the factors that hinder an enhanced understanding of the Santacrucian sloths.

De luliis et al. (2014) and Racco et al. (2018) provided partial clarification of the systematics of Eucholoeops ingens Ameghino, 1887, and Schismotherium fractum Ameghino, 1887, respectively. These recent efforts made use of material recovered after Scott's work, including the largely unpublished remains recovered by H.T. Martin (Kansas University Natural History Museum, Kansas, USA; Vizcaíno et al., 2016) and E. Riggs (Field Museum of Natural History, Chicago, USA; see Marshall, 1975, 1976), as well as those resulting from expeditions led by researchers of the Museo de La Plata (La Plata, Argentina), Museo Argentino de Ciencias Naturales "B. Rivadavia" (Buenos Aires, Argentina) and Duke University (Durham, USA). This collaboration began in 2003 and has continued to the present, with earlier efforts concentrated on costal localities between Monte León and Río Gallegos, and more recently on localities along the Río Santa Cruz and Río Chalía. The localities along the Río Santa Cruz and their fossils are the main focus of the current contribution. They are particularly relevant because the fossils recovered along the Río Santa Cruz by $C$. Ameghino formed the basis for F. Ameghino's (1887) initial descriptions of Santacrucian sloths (as well as other mammals; see Fernicola, 2011), and thus they are the type localities of many Santacrucian taxa. As several of the original fossils on which the 1887 taxa are based are no longer available (see below), the remains recovered by the joint expeditions mentioned above (housed at Museo Regional Provincial Padre M.J. Molina, Río Gallegos, Argentina) are potentially meaningful in helping resolve systematic issues. The present contribution explores their value in this regard, as well as considering the specimens that formed the basis for the species erected by Ameghino (1887). Further, the degree to which Scott's $(1903,1904)$ taxonomic and systematic actions should continue to be recognized is also assessed.

Of the numerous sloth genera erected on Santacrucian remains, only some half dozen -Schismotherium (with Pelecyodon Ameghino, 1891a, which probably cannot be distinguished from it; Racco et al., 2018), Eucholoeops, Hapalops,
Nematherium, Planops (these five erected on material from Río Santa Cruz localities), and Analcimorphus- have been considered sufficiently well represented for inclusion in the phylogenetic analyses. Gaudin (2004) and Amson et al. (2016) considered all six, whereas Pujos et al. (2007) included only Schismotherium, Hapalops, and Planops. The relationships of these genera among sloths are not entirely resolved. All three studies agree on the position of Eucholoeops as a basal Megalonychidae. The analysis by Pujos et al. (2007) was unable to resolve the positions of Hapalops and Planops. Gaudin (2004) and Amson et al. (2016) recognized Planops as a basal Megatheriidae (although the latter authors proposed the novel placement of Thalassocninae within this clade); Schismotherium, with Pelecyodon, as basal Megatherioidea; and Nematherium as among basal Mylodontidae. Gaudin (2004) hypothesized Analcimorphus and Hapalops as successive sister taxa to the clade including Megatheriidae and Nothrotheriidae, but noted that they could also be considered as successive sister taxa to Megalonychidae under different character weighting schemes. Amson et al. (2016) viewed Analcimorphus and Hapalops as successive sister taxa to Megalonychidae (all within an unnamed clade B), although the authors expressed reservation in noting that some of their arrangements are not particularly well supported. Prepotherium and Planops are regarded as Megatheriidae, as by, for example, De luliis (1994) and Gaudin (2004), respectively. Given the current understanding of these sloths, we recognize Eucholoeops as a basal megalonychid, Schismotherium, Analcimorphus, Hapalops, and Xyophorus as megatherioids, Planops and Prepotherium as megatheriids, and Nematherium as a mylodontid.

\section{Ameghino's collection from the Río Santa Cruz}

Ameghino (1887, p. 21-24) erected 110 taxa from the Río Santa Cruz, 14 of which were new sloth genera and species. He provided only species descriptions, without generic diagnoses. These taxa are, in order of publication, Schismotherium fractum, Eucholoeops ingens, E. infernalis, E. adteger, Hapalops rectangularis, $H$. indifferens, $H$. ellipticus, Trematherium intermixtum, Nematherium angulatum, N. sinuatum, Planops longirostratus, Xyophorus rostratus, $X$. simus, and Entelops dispar. In Figures 2 and 3 we provide images of the 
(1)

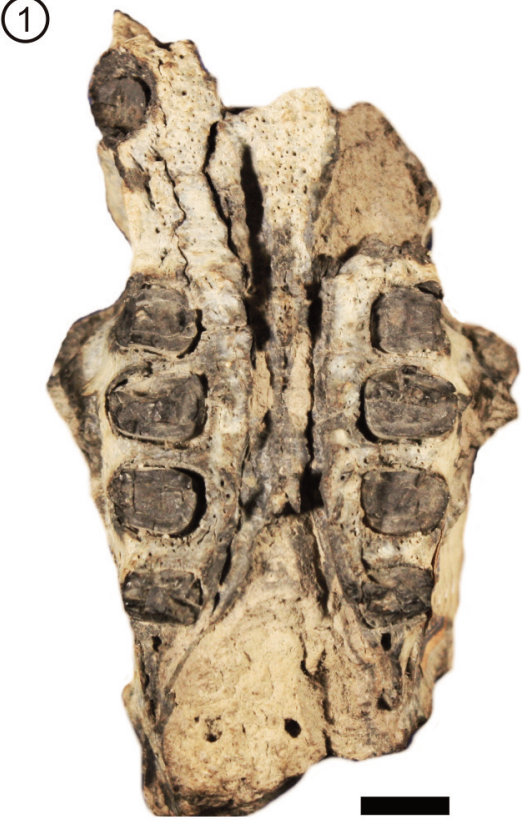

(2)

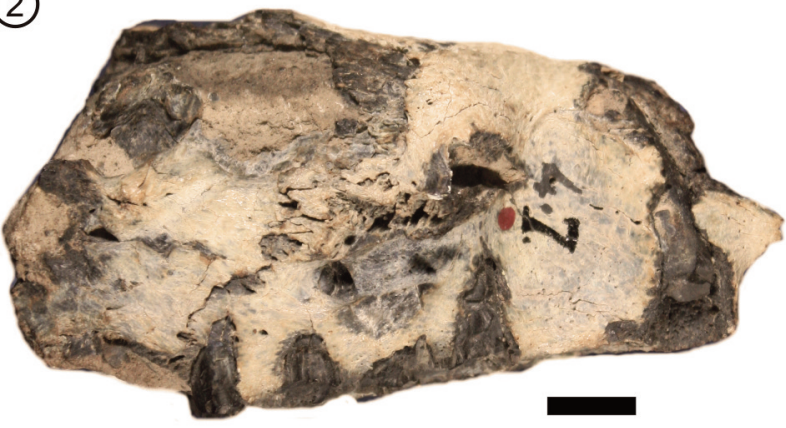

\section{(5)}

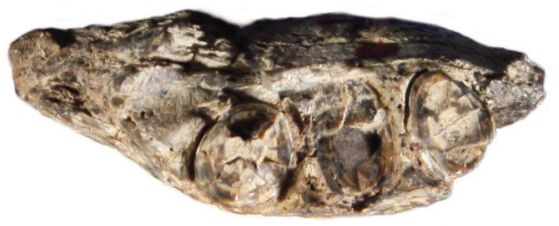

(4)
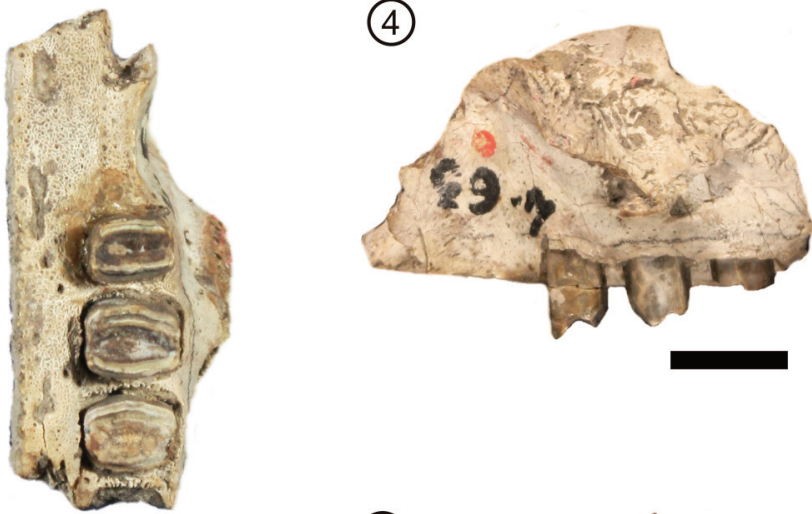

(6)

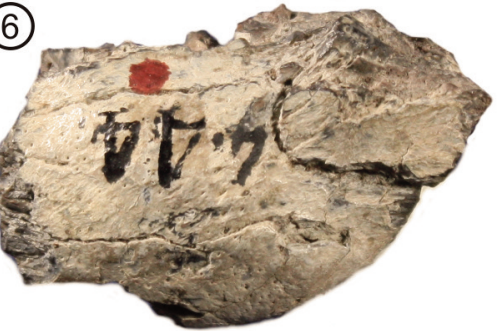

(9)

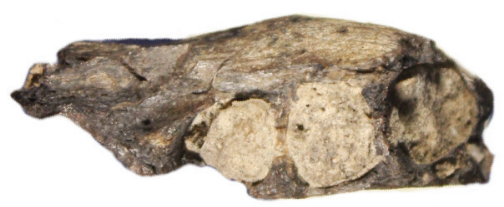

(7)

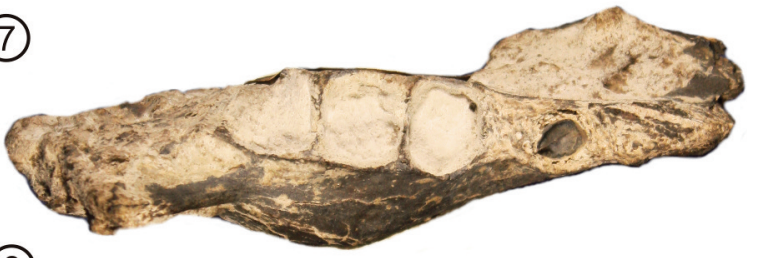

(8)

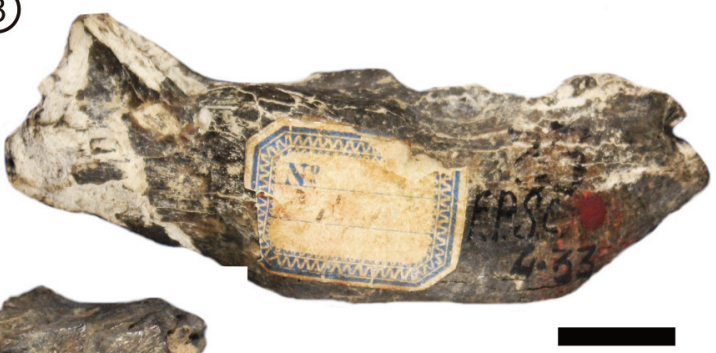

(10)

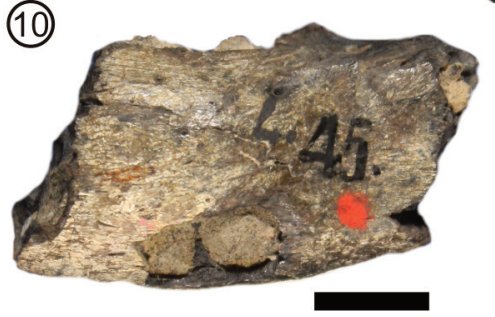

Figure 2. Type specimens of Ameghino's (1887) sloths housed at MLP. 1-2, Eucholoeops infernalis MLP 4-7, palatal view, and right lateral view of partial skull. 3-4, E. adteger MLP 4-63, palatal view, and left lateral view of a maxillary portion. 5-6, Hapalops ellipticus MLP 4-44, occlusal view, and left lateral view of a partial dentary. 7-8, $\mathrm{H}$. indifferens MLP 4-33, occlusal view, and right lateral view of a mandibular ramus. 9-10, Trematherium intermixtum MLP 4-45, occlusal view, and left lateral view of a partial dentary. Scale bars= $1 \mathrm{~cm}$. 
few original types of Ameghino (1887) that are currently available in the Museo de La Plata.

In addition to these, Ameghino (e.g., 1889, 1891a, b, $1894,1897)$ subsequently named numerous additional sloth genera and species (as well as other mammalian taxa) based mainly on specimens recovered from coastal localities of the SCF. Fernicola (2011) provided a detailed description of the historical context related to the collection made by C. Ameghino at the Río Santa Cruz and the destiny of the fossils. This author reviewed all specimens listed in Ameghino (1887) that were later figured in Ameghino (1889), and/or were located recently in the Colección Nacional Ameghino at the Museo Argentino de Ciencias Naturales "Bernardino Rivadavia". Fernicola (2011) also indicated that Ameghino (1889) figured 64 of the 110 new species published in 1887; of these new taxa figured, 19 were collected at the Río Santa Cruz, 15 of which were recovered by his brother Carlos. Vizcaíno et al. (2013a, b) went a step further in the history of Santacrucian collections, and reviewed the fate of the "Old Collections" of the Museo de La Plata that may have included specimens sent abroad during the $20^{\text {th }}$ century.

\section{MATERIAL AND METHODS}

Acronyms. AMNH, American Museum of Natural History, New York, USA; FMNH, Field Museum of Natural History, Chicago, USA; KUNHM, Kansas University Natural History Museum, Lawrence, USA; MACN-A, Museo Argentino de

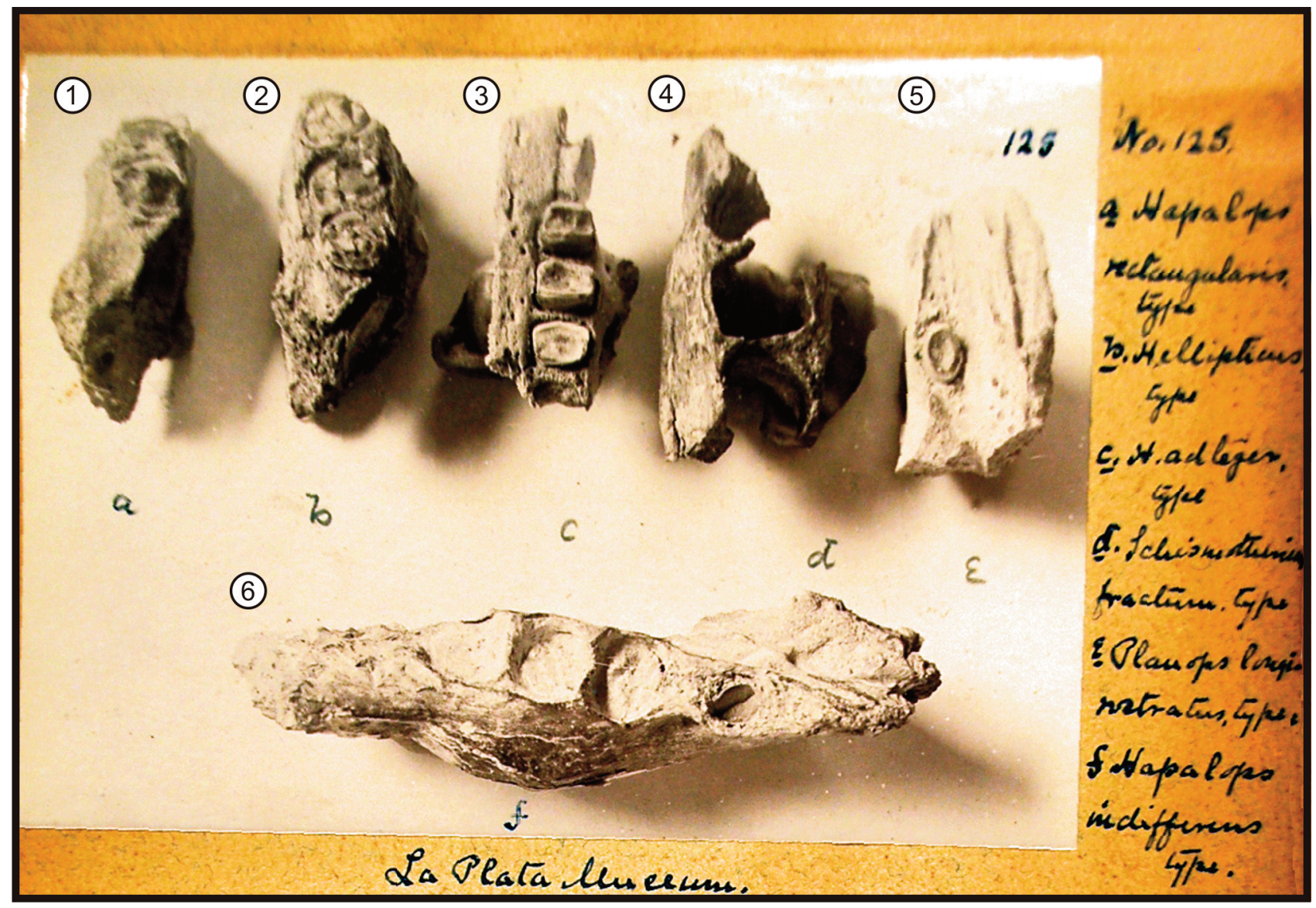

Figure 3. Figure 125 of Scott's album (from Vizcaíno et al., 2017, Suppl. files, Appendix 1, p. 66), including photographs in occlusal view of several of the sloth type specimens of Ameghino (1887). 1, Hapalops rectangularis (lost); 2, H. ellipticus; 3, Eucholoeops adteger; 4, Schismotherium fractum (lost and never figured); 5, Planops longirostratus (lost and never figured); 6, H. indifferens. Scott's album is archived in the Department of Paleontology of KUNHM. 
Ciencias Naturales "Bernardino Rivadavia," Colección Nacional Ameghino, Buenos Aires, Argentina; MLP, Museo de La Plata, La Plata, Argentina; MPM-PV, Museo Regional Provincial Padre M.J. Molina, Río Gallegos, Argentina; NHMUK, Natural History Museum, London, United Kingdom; YPMVPPU, Yale Peabody Museum, Vertebrate Paleontology, Princeton University Collection, New Haven, USA.

Other abbreviations. cf, lower caniniform; Cf, upper caniniform; Ea., Estancia; L, left; mf, lower molariform; Mf, upper molariform; $\mathrm{R}$, right.

Recent fieldwork carried out between 2013 and 2014 by joint expeditions of the MLP, MACN, and Duke University recovered 69 remains of fossil sloths. This collection belongs to the MPM-PV and is listed in Appendix 1. The specimens collected include mostly postcranial elements (fragmentary long bones, several pes and manus elements, for example) and some skull and mandibular fragments. They were recovered from two fossiliferous localities: Barrancas Blancas (BB; 20 specimens) and Segundas Barrancas Blancas (SBB; 49 specimens). No sloth remains were recovered from Yaten Huageno (YH). The list of specimens studied and used for comparison is provided in Appendix 2.

\section{SYSTEMATIC PALEONTOLOGY}

Xenarthra Cope, 1889

Folivora Delsuc, Catzeflis, Stanhope, and Douzery, 2001

Megatherioidea Gray, 1821

Genus Hapalops Ameghino, 1887

Type species. H. rectangularis Ameghino, 1887. Santa Cruz Formation, Barrancas del Río Santa Cruz, Province of Santa Cruz, Argentina.

Hapalops cf. elongatus Ameghino, 1891a

Figures 4, 5.1-3, Table 1

Referred material. MPM-PV 19353 (Fig. 4), anterior portion of skull preserving palate with all teeth; molariforms are set in their alveoli, whereas the Cf1s are isolated and only the distal portion of their alveolus is preserved; distal portion of $R$ humerus, $R$ and $L$ humeral heads, central humeral diaphysis, $R$ radius, proximal $R$ ulna; several podial elements; $L$ distal femur and partial $\mathrm{R}$ diaphysis, several fragments of vertebrae and of ribs; several sternebrae. MPM-PV 19352 (Fig. 5.1), portion of R dentary preserving cf1-mf3, with cf1 broken above level of alveolar margin. MPM-PV 19317 (Fig. 5.2), portion of R dentary preserving distal part of cf1 alveolus, mf1 and mf2 completely, and all but distolingual portion of mf3. MPM-PV 19318 (Fig. 5.3), anterior portion of skull, preserving L Cf1, Mf1-Mf3, Mf4 broken, and R Mf1Mf3 (Mf1 broken vestibularly and Mf2 lacking its occlusal surface), and a small portion of Mf4.

Geographic occurrence. MPM-PV 19352 and 19353, Segundas Barrancas Blancas (Ea. Cordón Alto); MPM-PV 19317 and 19318, Barrancas Blancas (Ea. Santa Lucía), Río Santa Cruz, Province of Santa Cruz, Argentina.

Stratigraphic occurrence. Santa Cruz Formation (Early-Middle Miocene).

Description. In MPM-PV 19353 (Fig. 4) and 19318 (Fig. 5.3) the Cf1 is cylindrical to oval, slightly vestibulolingually compressed, with major axis oblique to the long axis of the tooth row, and separated from the cheek teeth by a diastema. The molariforms are rectangular in section (that is, mesiodistally compressed), with Mf2 being the largest and Mf4 being the smallest. The mesial tooth, cf1, of MPM-PV 19352 (Fig. 5.1) is nearly cylindrical in section and the smallest tooth. A diastema separates it from mf1. The mesial molariforms, $\mathrm{mf} 1$ and $\mathrm{mf} 2$, are rectangular, with the surfaces of each tooth meeting angularly. They are more nearly squared in section, particularly $\mathrm{mf2}$, compared to those in some other Hapalops species, owing to their increased mesiodistal length (see below). The distal cheek tooth, $\mathrm{mf3}$, is nearly cylindrical in section and with its major axis set obliquely to the long axis of the tooth row. The occlusal surfaces of the teeth are not preserved, as the teeth are broken near the level of their alveolar margin. In MPM-PV 19317 (Fig. 5.2) the diastema is slightly shorter than in MPM-PV 19352. Of the molariform teeth, $\mathrm{mf} 1$ and $\mathrm{mf2}$ are nearly squared, similar to those of MPM-PV 19352, and mf3 is nearly cylindrical in shape, with major axis set obliquely to the long axis of the tooth row.

Comments. In MPM-PV 19353 and 19318 the molariforms are similar in form, with the former being larger. These teeth appear more mesiodistally compressed than in the type of Eucholoeops adteger (MLP 4-63; Fig. 2.3-4, 3.3) although the latter is approximately intermediate in size. MLP 4-63, how- 

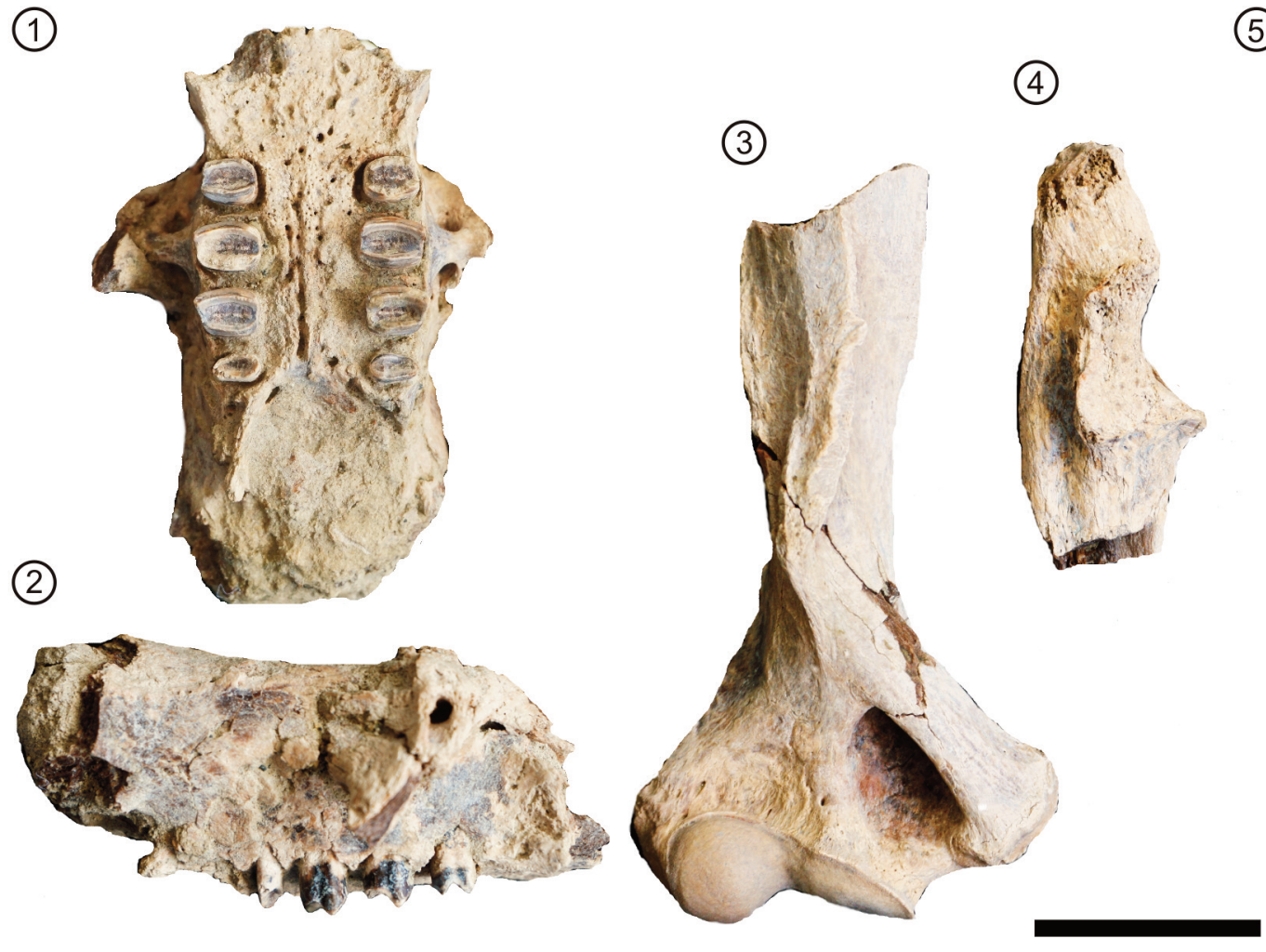

(5)

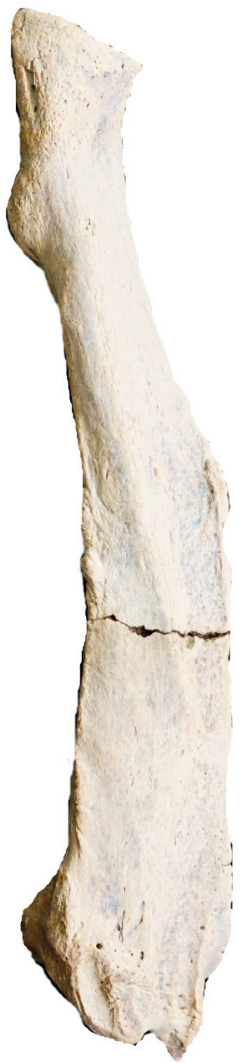

Figure 4. Hapalops cf. elongatus MPM-PV 19353. 1, anterior portion of skull in palatal view; 2, anterior portion ofskull in right lateral view; 3, right humerus, anterior view; 4, proximal portion of right ulna, lateral view; 5, right radius, lateral view. Scale bar= $3 \mathrm{~cm}$.

ever, belongs to a very young individual, as judged by the open intermaxillary suture, and may thus represent a larger species with more square molariforms, such as E. infernalis (MLP 4-7; Fig. 2.1-2). The palatal width of MPM-PV 19353 and 19318 is narrower than in Hapalops platycephalus (YPM-VPPU 15564) and more similar to the condition in $H$. elongatus (e.g., YPM-VPPU 15011, 15597, 15545, and 15160) and $H$. ruetimeyeri (e.g., AMNH 9250 and 9293, the latter as $H$. ruetimeyer? by Scott, 1904). Confident assignment of both MPM-PV specimens to species is not possible, but as they are closer in size to the remains that Scott (1903, 1904 ) assigned to $H$. elongatus rather than $H$. ruetimeyeri, they are tentatively assigned to the former.

The nearly cylindrical mf3 of MPM-PV 19352 is the usual form of this tooth in Hapalops species, as well as in Eucholoeops and Schismotherium; as noted below, this morphology is diagnostic neither specifically not generically. MPM-PV 19352 is most similar morphologically and metri- cally to several specimens that Scott (1903, 1904: pl. 40, figs. 2-4) assigned to and illustrated as $H$. elongatus; hence its tentative assignment here to this species. The form of its molariform teeth are similar to that of YPM-PU 15110, assigned by Scott (1903: pl. 34, figs. 4, 5) to H. indifferens, but the latter is larger. Hapalops elongatus and $H$. indifferens are closely similar in dental morphology, but judging by the preserved portion of the mandibular spout of $\mathrm{H}$. indifferens, it appears that the spout would have been longer than that of $H$. elongatus. It is considerably smaller than the remains assigned by Scott (1903) to H. longiceps, in which mf1 and $\mathrm{mf} 2$ are also rectangular rather than more nearly squared. The specimen, AMNH 9222, that Scott (1904: pl. 40, fig. 1, 1a) assigned to and figured as $H$. rectangularis is similar in size to MPM-PV 19352 and the $H$. elongatus remains, but mf1 and mf2 are more transversely expanded and thus more rectangular in the AMNH specimen.

MPM-PV 19317 strongly resembles MPM-PV 19352 
in size and morphology of the molariforms, although the diastema appears slightly shorter. Although cf1 is not preserved, the homologous portions of MPM-PV 19317, as with MPM-PV 19352, sufficiently resemble in size and form those of remains assigned by Scott $(1903,1904)$ to $H$. elongatus to permit tentative assignment of MPM-PV 19317 to this species.

Genus Schismotherium Ameghino, 1887

Type species. Schismotherium fractum Ameghino, 1887. Santa Cruz Formation, Barrancas del Río Santa Cruz, Province of Santa Cruz, Argentina.

Schismotherium cf. fractum Ameghino, 1887

Figure 5.4, Table 1

Referred material. MPM-PV 19328, portion of $L$ dentary with mf1-2 alveoli, and alveoli of cf1 and mf3 incomplete, and two ungual phalanges (one complete and one partial).

Geographic occurrence. Segundas Barrancas Blancas (Ea. Cordón Alto), Río Santa Cruz, Province of Santa Cruz, Argentina. Stratigraphic occurrence. Santa Cruz Formation (Early-Middle Miocene).

Description. Although the specimen MPM-PV 19328 is incomplete (Fig. 5.4), there is clearly no diastema between the first and second alveoli. The preserved portion of the first alveolus suggest that the tooth was approximately cylindrical or oval and thus caniniform. The mf1 and mf2 alveoli suggest that the molariform teeth were oval and transversely expanded.

Comments. The lack of a diastema of MPM-PV 19328 excludes, among similarly sized specimens, remains assigned to Hapalops, Eucholoeops, and Xyophorus. The molariform teeth, oval and transversely expanded, also rules out Nematherium. Among reasonably well-known Santacrucian sloths, MPM-PV19328 most closely resembles the mandible

Figure 5. 1-3, Hapalops cf. elongatus. 1, MPM-PV 19352, right dentary, oclusal (upper) and right lateral view (lower); 2, MPM-PV 19317, right dentary, occlusal (upper) and right lateral view (lower). 3, MPMPV 19318, anterior portion of skull in palatal view. 4, Schismotherium cf. fractum MPM-PV 19328, portion of left dentary, occlusal view. Scale bars $=1 \mathrm{~cm}$.

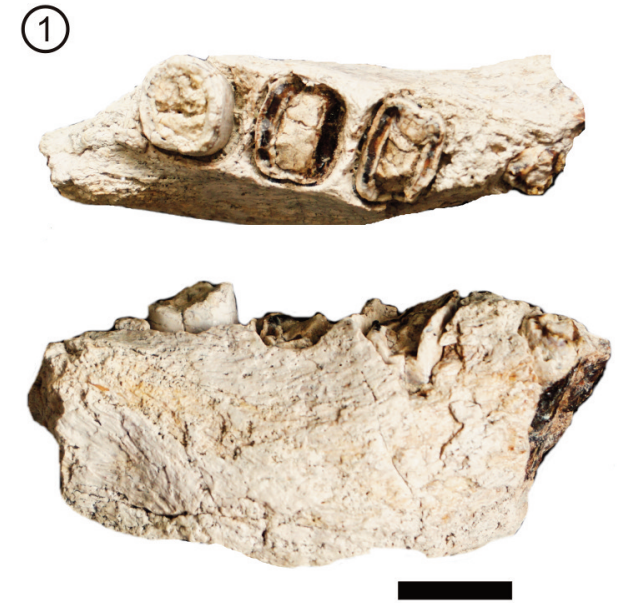

(2)
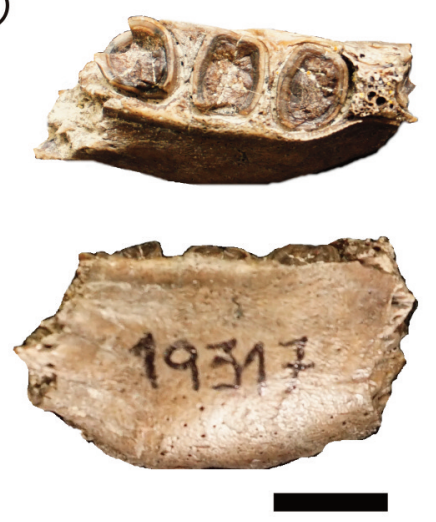

(3)

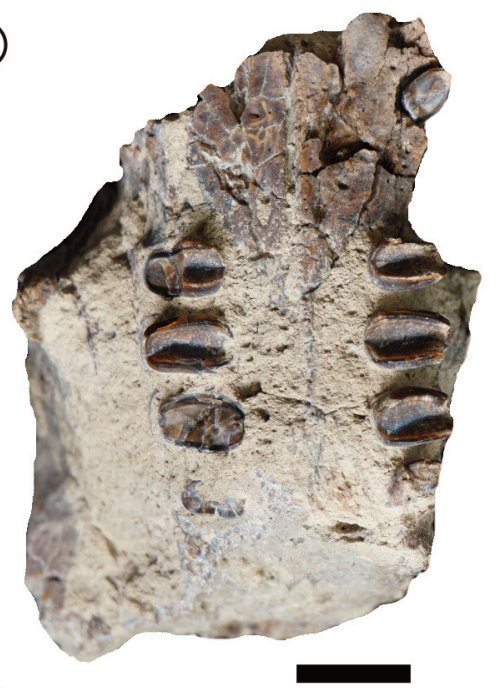

(4)

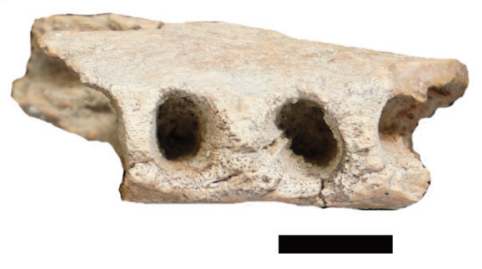


TABLE 1 - Skull and mandible measurements (in $\mathrm{mm}$ ) of the new specimens reported, as in De luliis et al. (2014)

\begin{tabular}{|c|c|c|c|c|c|c|c|c|}
\hline \multirow[t]{2}{*}{ Skull } & \multicolumn{2}{|c|}{ Hapalops $c f$. elongatus } & \multirow[t]{2}{*}{ Mandible } & \multicolumn{2}{|c|}{ Hapalops $c f$. elongatus } & \multirow{2}{*}{$\begin{array}{c}\text { Schismotherium } \\
\text { cf. fractum }\end{array}$} & \multirow{2}{*}{$\begin{array}{c}\begin{array}{c}\text { Xyophorus } \\
\text { atlanticus }\end{array} \\
\text { MPM-PV } 19337\end{array}$} & \multirow{2}{*}{$\begin{array}{c}\begin{array}{c}\text { Nematherium } \\
\text { longirostris }\end{array} \\
\text { MPM-PV } 19326\end{array}$} \\
\hline & MPM-PV 19353 & MPM-PV 19318 & & MPM-PV 19352 & MPM-PV 19317 & & & \\
\hline$c f 1$ & - & $4.50 / 5.25$ & $c f 1$ & $4.77 / 5.49$ & - & - & - & - \\
\hline Mf1 & $7.28 / 5.88$ & $7.12 / 4.92$ & $m f 1$ & $9.83 / 7.13$ & $7.26 / 6.17$ & $8.33 / 6.71$ & $8.75 / 5.61$ & $5.72 / 7.29$ \\
\hline$M f 2$ & $8.44 / 6.42$ & $9.02 / 5.28$ & $m f 2$ & $9.45 / 7.25$ & $7.10 / 6.40$ & $8.63 / 6.37$ & $8.80 / 6.15$ & $7.03 / 7.88$ \\
\hline$M f 3$ & $8.26 / 6.56$ & $7.44 / 5.06$ & $m f 3$ & $8.16 / 7.38$ & $7.58 / 6.81$ & - & $8.35 / 8.15$ & $6.98 / 6.05$ \\
\hline Mf4 & $6.54 / 3.98$ & $\sim 5.62 / \sim 4.17$ & H Ramus & - & - & 21.62 & 18.25 & $5.46 / 7.28$ \\
\hline$\angle C F 1-O C$ & - & - & $L c f 1-m f 3$ & 35.80 & - & - & - & - \\
\hline$L C f 1-M f 4$ & - & 39.92 & L Dias Mand & 6.40 & $\sim 4.06$ & - & - & - \\
\hline LDias & 10.73 & 11.19 & LMand & - & - & - & - & - \\
\hline L Mf1-Mf4 & 29.04 & 24.36 & $L m f 1-m f 3$ & 25.79 & 21.58 & - & 21.76 & - \\
\hline$W C f 1$ & $\sim 33.26$ & - & LSpout & - & - & - & - & - \\
\hline W Dias & 10.92 & - & & & & & & \\
\hline W Mast & - & - & & & & & & \\
\hline W $M f 3$ & 26.61 & $\sim 26.38$ & & & & & & \\
\hline W Pal & 11.22 at M2 & 10.40 at $M 2$ & & & & & & \\
\hline W Pal Cf1 & 21.64 & - & & & & & & \\
\hline W Postorb & - & - & & & & & & \\
\hline W Preorb & - & $\sim 27.50$ & & & & & & \\
\hline W Temp & - & - & & & & & & \\
\hline
\end{tabular}

Skull and upper teeth: Cf1, transverse/mesiodistal diameters of caniniformor its alveolus; Mf1-Mf4, transverse/mesiodistal diameters of molariform teeth or their alveoli; LCF1-OC, length from the mesial margin of Cf1 or of its alveolus to the posterior margin of the occipital condyles; L Cf1-Mf4, length from the mesial margin of Cf1 to the distal margin of Mf4 or of their alveoli; L Dias, diastema length; L Mf1-Mf4, length from the mesial margin of Mf1 to the distal margin of Mf 4 or of their alveoli; W Cf1, maximum width across maxillae at level of Cf15; W Dias, maximum width across maxillae at level of diastemata; W Mast, skull width across mastoid processes; W Mf3, maximum width between lateral borders of M3 alveoli; W Pal, minimum palatal diameter at M- (see Table); W Pal Cf1, palatal width between Cf1s or their alveoli; W Postorb, width at postorbital constriction; W Preorb, dorsal width at preorbital constriction; W Temp, width between temporal lines; , estimated measurement. Mandible and lower teeth: cf1, transverse/mesiodistal diameters of caniniform or its alveolus; $\mathrm{mf1}$-mf3, transverse/mesiodistal diameters of molariform teeth or their alveoli; $\mathrm{H}$ Ramus, maximal height of horizontal ramus at m3. L cf1-mf3, length from the mesial margin of $c 1$ to the distal margin of $\mathrm{mf} 3$ or of their alveoli; $L$ Dias Mand, length of mandibular diastema; L Mand, maximal mandibular length from anterior margin of spout to posterior margin of mandibular condyle; L mf1-mf3, length from the mesial margin of $m 1$ to distal margin of $m 3$ or of their alveoli; $L$ Spout, length of the spout from anterior to posterior margins of mandibular symphysis; , estimated measurement.

(MACN-A 6446) of Schismotherium fractum. The specimen is therefore tentatively assigned to this species. This decision reflects the suggestion by Racco et al. (2018) that Pelecyodon may not be distinguishable from Schismotherium.

\section{Genus Xyophorus Ameghino, 1887}

Type species. Xyophorus rostratus Ameghino, 1887. Santa Cruz Formation, Barrancas del Río Santa Cruz, Province of Santa Cruz, Argentina.

Xyophorus atlanticus Ameghino, 1891a

Figure 6, Table 1
Referred material. MPM-PV 19337, partial L and R dentaries; $L$ dentary preserving mf1-mf3 completely (occlusal surface of mf2 and mf3 broken); R dentary preserving mf2-mf3 completely, incomplete alveolus of mf1 with a tooth fragment; several incomplete vertebrae; proximal portions of $\mathrm{R}$ radius and $L$ and $R$ ulnae; nearly complete $L$ femur; distal part of $R$ femur; proximal portion of $L$ tibia; $R$ astragalus; several skeletal fragments.

Geographic occurrence. Segundas Barrancas Blancas (Ea. Cordón Alto), Río Santa Cruz, Province of Santa Cruz, Argentina. 
Stratigraphic occurrence. Santa Cruz Formation (EarlyMiddle Miocene).

Description. The mf1 and mf2 of MPM-PV 19337 (Fig. 6.1) are compressed mesiodistally, particularly $\mathrm{mf1}$, which is rectangular with slightly rounded corners, whereas $\mathrm{mf} 2$ is nearly rectangular. The $\mathrm{mf} 3$ is approximately cylindrical, with major axis set obliquely to the long axis of the tooth row. The radius bears an elliptical head, with a nearly flat ulnar facet, and a prominent bicipital tuber. The ulna (Fig. 6.2) possesses a well-developed olecranon process, aligned with the long axis of the diaphysis, and the semilunar notch is wide and triangular in anterior view. The radial notch is wide and flat. The femur (Fig. 6.3) has a gracile and nearly rectilinear diaphysis (bearing only a slight diaphyseal deflection); its head is spherical, with a distinct neck, and is flanked by a low greater trochanter and a pyramidal lesser trochanter. The well developed and distinct third trochanter projects laterally from midshaft. Distally the femur bears a wide and shallow patellar groove that is contiguous with both the medial and lateral condyles, of which the former is larger. The tibial plateau (Fig. 6.4) bears a flat medial condyle, with a proximally projected lateral margin that forms a sharp intercondyloid eminence and a convex lateral margin that descends to contact the fibular facet posteriorly. The tibial tuberosity is rugose and flat, and projects laterally. The astragalus (Fig. 6.5-7) possess a triangular trochlea tali, almost as wide as long, with gently convex condyles. The fibular facet is orthogonal to the trochlea, and the head, which bears a long and well defined neck, is triangular in anterior view, with an anteriorly protruding lateral lip and a smooth and rounded medial one. The navicular facet is concave and triangular. The cuboidal facet is flat and well defined and the sustentacular facet is convex and medially inclined. The ectal facet contacts the fibular facet only anteriorly.

Comments. In size and form the dentary portions, including the teeth, of MPM-PV 19337 are closely similar to those of the type of Xyophorus atlanticus (MACN-A 4631). Characteristic of the latter, and MPM-PV 19337, is that mf1 and $\mathrm{mf} 2$ are strongly compressed mesiodistally, with $\mathrm{mf} 2$ being rectangular and mf1 nearly so (the corners of this tooth are slightly rounded). The postcranial remains are quite representative of most Santacrucian sloths. The elliptical head of the radius is similar to that of Hapalops longiceps (YPMVPPU 15523) and Eucholoeops ingens (MPM-PV 3451). The wide, triangular semilunar notch is similar to that of Schismotherium fractum (MACN-A 6445-6470) and differs from the narrow notch of Hapalops longiceps (YPM-VPPU 15523). The anconeal process is deflected laterally and the coronoid process is deflected medially. The femur is typical of stem megatherioid Santacrucian sloths, differing from the massive femur of Prepotherium potens (YPMVPPU 15345). The well-developed third trochanter, projects laterally from midshaft, in contrast to the robust and proximodistally elongated third trochanter of Prepotherium potens. The morphology of the femur distally is characteristic of most Santacrucian sloths (see, for example, Hapalops longiceps YPM-VPPU 15523), as does that of the tibia proximally. The astragalus bears a general overall similarity to that of other Santacrucian sloths. The ectal facet contacts the fibular facet only anteriorly, leaving a posteriorly wide opening for the ligamentary fovea as in Xyophorus simus (MACN-A 4617-4618 and an unnumbered astragalus), while in other similarly-sized Santacrucian sloths (i.e., not Prepotherium, see below) the facets contact each other both anteriorly and posteriorly (e.g., S. fractum FMNH 13137), or the posterior isthmus is narrower (e.g., H. longiceps YPMVPPU 15523). Besides the features described above, the astragalus of MPM-PV 19337 shows several peculiarities that differentiate it. For example, the trochlea tali in dorsal view (Fig. 6.5) is shorter and more regularly triangular; the concave ectal facet is more rectangular (rather than crescent-shaped), is laterally inclined, and meets the fibular facet at an obtuse angle (rather than orthogonal, as in, e.g." Hapalops species, and S. fractum); in plantar view (Fig. 6.6), the ectal facet diverges more markedly posteriorly from the fibular facet, adopting a more oblique condition than occurs in $\mathrm{H}$. Iongiceps; and the sulcus tali is wider.

MegatheriIdae Gray, 1821

Planopinae Simpson, 1945

Planopinae indet.

Figure 7. 1-6

Referred material. MPM-PV 19323 (Fig. 7.1-3), R astragalus. 
(1)
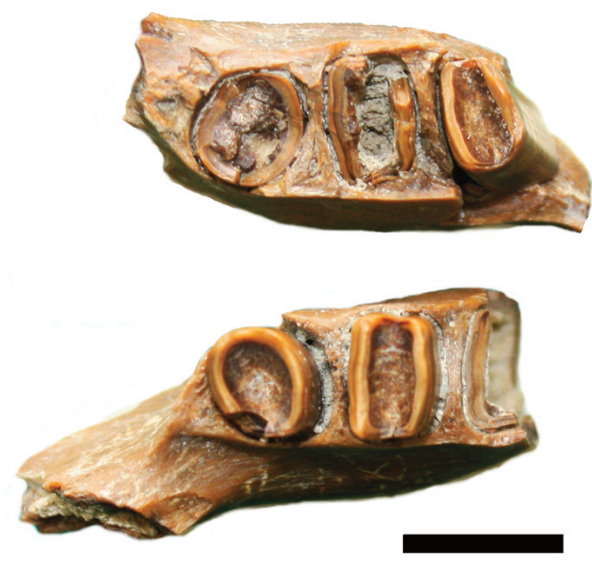

(5)

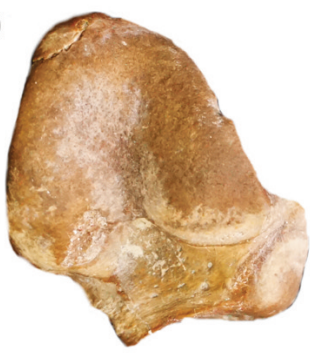

(6)

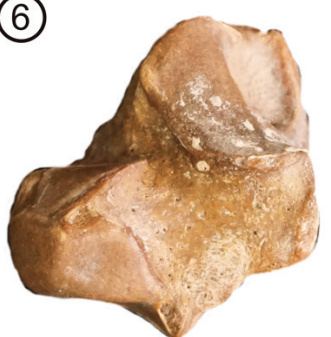

(7)

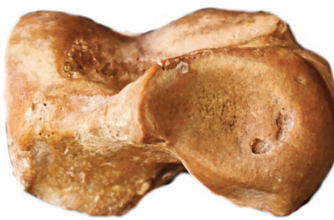

(2)

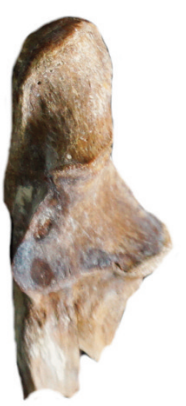

(3)

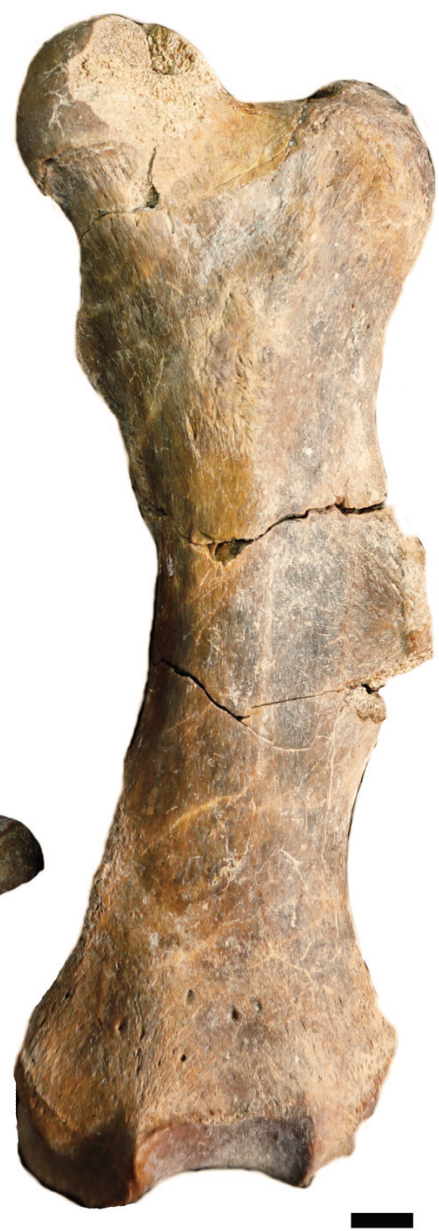

Figure 6. Xyophorus atlanticus MPM-PV 19337. 1, left (upper) and right (lower) partial dentaries in occlusal view; 2, proximal portion of right ulna, anterior view; 3, left femur in anterior view; 4, proximal portion of left tibia in anterior view; 5-7, right astragalus in 5, dorsal, 6, plantar, and 7 , anterior views. Scale bars $=1 \mathrm{~cm}$.

MPM-PV 19358 (Fig. 7.4-6), proximal two-thirds and distal epiphysis of a $\mathrm{R}$ humerus; proximal portion, patellar trochlea, and lateral distal condyle of a $L$ femur; proximal epiphysis, nearly complete, and distal half of a R tibia; distal portion of a $\mathrm{R}$ fibula, including articular surfaces.

Geographic occurrence. Segundas Barrancas Blancas (Ea. Cordón Alto), Río Santa Cruz, Province of Santa Cruz, Argentina.

Stratigraphic occurrence. Santa Cruz Formation (Early-Middle Miocene).

Description. The astragalus, MPM-PV 19323 (Fig. 7.1-3), is short and massive. Its trochlea tali is wide and comparatively short, bearing a deep trochlear sulcus. The medial trochlear condyle (odontoid process) is rounded and short.
The lateral trochlear condyle, gently convex, bears the discoid facet and is longer than the medial trochlear condyle. The fibular facet is flat, with its proximal margin contacting the lateral trochlear condyle. In anterior view it meets the trochlear plane at a right angle. The head is wide and bulky, with a very short neck, and hence the navicular facet is coincident with the anterior most margin of the lateral trochlear condyle. The facet for the navicular is composed of a concave, elliptical, mediolaterally elongated, and anteriorly-facing lateral portion and a smaller, convex, mediallyfacing portion. Ventrally the head bears a convex and smooth cuboidal facet. The elliptical and convex sustentacular facet is inclined medially. The ectal facet is crescentic and con- 
cave, and closely approaches the fibular facet anteriorly, leaving a ligamentary lateral fovea that is widely opened posteriorly. A wide and deep sulcus tali opens between sustentacular and ectal facets.

MPM-PV 19358 (Fig. 7.4-6) comprises partially preserved long bones and several fragmentary remains of other elements. Their large size is notable. The humerus shows a round head, projecting more proximally than the tuberosities, and a well-developed and elongated deltopectoral shelf (Fig. 7.4). The distal epiphysis is wide, with a round capitulum and a medially elongated trochlea (Fig. 7.5). The cochlea tibiae is wider than long, with clear and distinct grooves for the astragalar odontoid and discoid facets (Fig. 7.6). The process for the flexor tendons is conspicuous. The distal portion of the fibula bears a robust malleolus, with a flat tibial facet, a triangular to crescentic facet for the astragalus, and a posterior isthmus for ligaments.

Comments. MPM-PV19323 strongly resembles the holotype of Prepotherium potens MACN-A 4694 and the astragali of the holotype of Planops martini (NHMUK PV M 43404) in the features described above, including size. In this sense, the astragalus of this specimen, as well as of Prepotherium potens and Planops martini, is at least $20 \%$ larger than in the next largest Santacrucian sloths (e.g., Analcimorphus giganteus, YPM-VPPU 15561, and Hapalops longiceps, YPM-VPPU 15523). The peg-shaped medial trochlear condyle resembles the peg-shaped morphology present in later megatheriines and mylodontids, and differs from the condition in other species such as $H$. longiceps, $A$. giganteus, and Schismotherium fractum (FMNH 13137), while the lateral trochlear condyle is more elongated. The trochlear sulcus is also deeper. The short-necked head is similar to that of both Prepotherium and Planops while, conversely, in the other above-mentioned sloths the neck is conspicuous, and the same is true for an astragalus assigned dubiously to Nematherium (YPM-VPPU 15965, see Scott, 1904). The sustentacular facet differs from that described for Nematherium, where it is divided into two flat and orthogonally disposed facets; a similar morphology is described by Hoffstetter (1961) for Planops martini. This appears to be the only difference with Planops. In other Santacrucian sloths the posterior portions of the fibular and ectal facets approach each other closely, conversely to the condition in this specimen and in Prepotherium. The fibular facet of Prepotherium is more extensive anteriorly and is contiguous with the ectal facet, rendering the fovea much shorter; and the two facets are widely separated posteriorly, so that the fovea is also taller. These details, along with a less posteriorly positioned odontoid process, are the only differences with Prepotherium. The astragalus also strong resembles that of the Early Miocene Planopinae Prepoplanops boleadorensis (MLP 97-XI-3-1) from Cerro Boleadoras Formation (Northwestern of the Province of Santa Cruz) as described in Carlini et al. (2013).

Summarizing, the large size of this specimen and the development of its medial trochlear condyle align it to the Santacrucian sloths described as Prepotherium and Planops, which have been variably assigned, within Megatheriidae, to Planopinae (see Mones, 1986) or Prepotheriina (see McKenna and Bell, 1997), although Planopinae appears to be more current. However, the differences of MPM-PV 19323 from one or the other genus preclude confident generic assignment. Therefore, it is assigned only to Planopinae.

In addition to the elements listed above for MPM-PV 19358, this specimen includes several additional partial elements of a single individual. The listed remains are those that are sufficiently preserved to permit comparisons. They are relatively massive compared to the sloth remains typically recovered from the SCF, and thus compare closely in size with the homologous portions of elements of Planops martini(Hoffstetter, 1961: NHMUK PV M 43404), Prepotherium potens (YPM-VPPU 15345), and Prepoplanops boleadorensis (MLP 97-XI-3-1; Carlini et al., 2013). Examples of such dimensions are the width across the humeral deltopectoral shelf and distal humeral articular surface, and width of the cochlea tibiae of the tibia. MPM-PV 19358 also closely resembles morphologically the remains of these two species in such features as the shape of the humeral head and tuberosities and their relative positions, shape and extent of the humeral deltopectoral shelf, shape of the greater trochanter of the femur, and size and shape of the cochlea tibiae. The shape of the medial portion of the cochlea tibiae suggests that the medial astragalar condyle was peg shaped, as occurs in Planops and Prepotherium. Other large humeri recovered from Santacrucian levels have been recognized as mylodontid (e.g., YPM-VPPU 15374), but that of MPM-PV 19358 does not possess as expanded a del- 
(1)

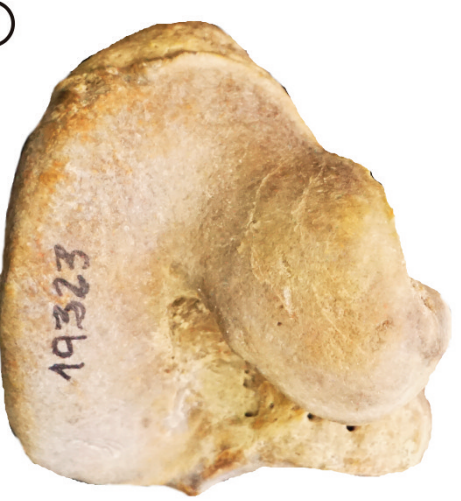

(4)

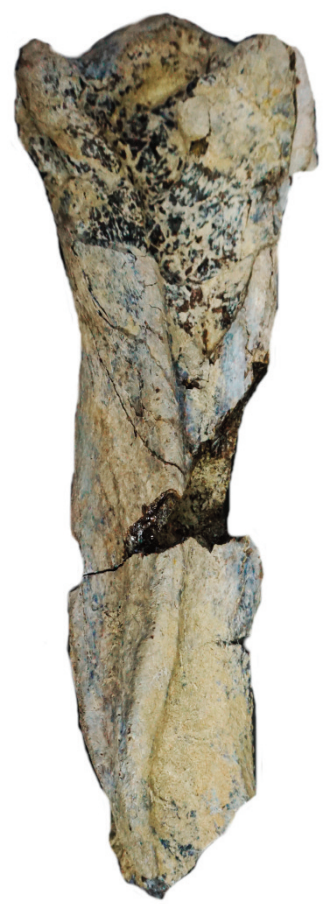

(5)

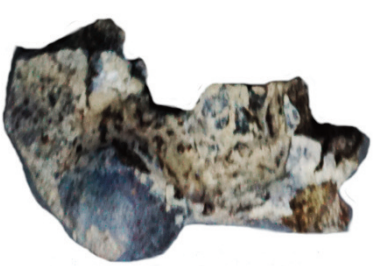

(2)

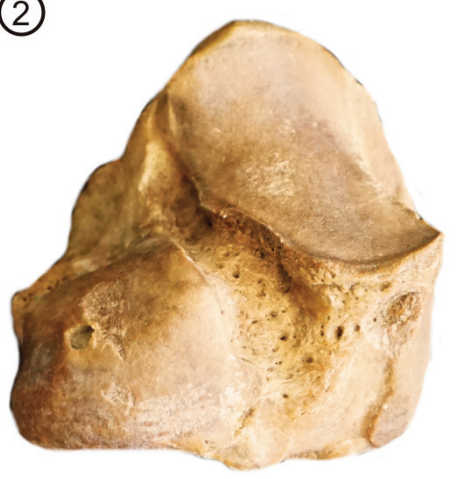

(3)

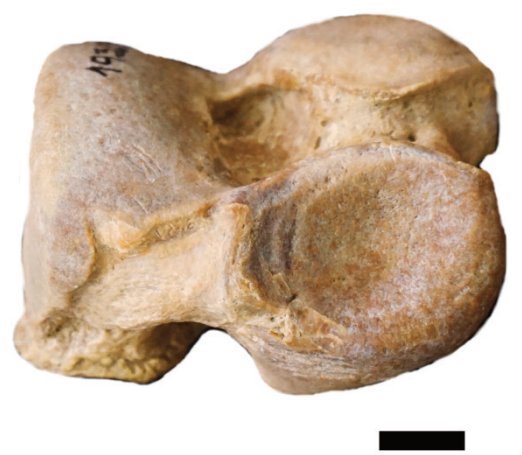

(6)

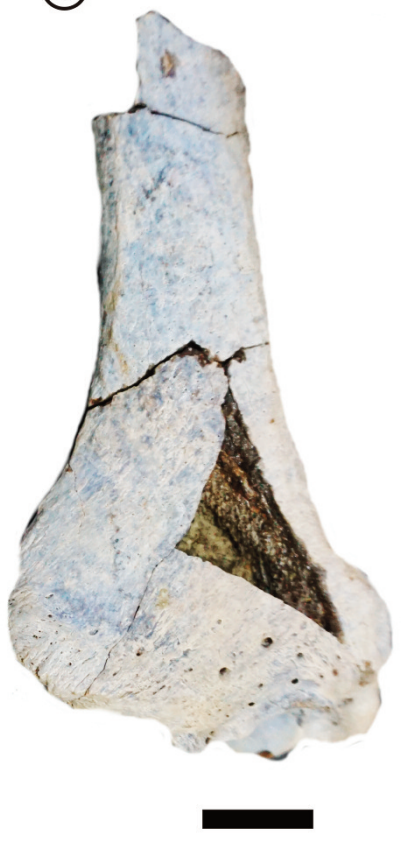

(7)

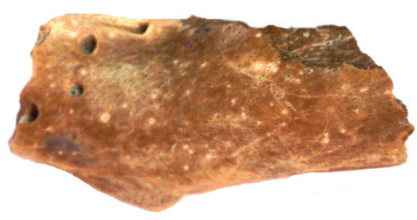

(8)
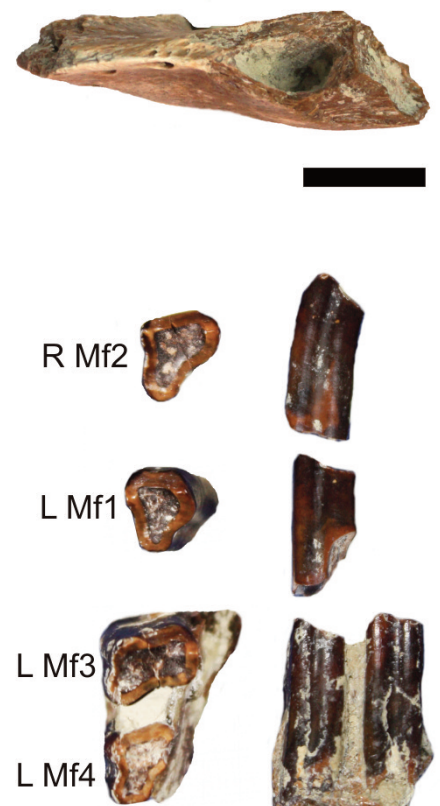

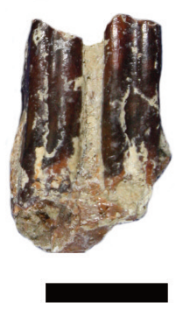

Figure 7. Planopinae indet. MPM-PV 19323, right astragalus. 1, dorsal view; 2, plantar view; 3, anterior view. Scale bar= $1 \mathrm{~cm}$. MPM-PV 19358. 4, proximal portion of right humerus in anterior view; 5 , distal epiphysis of right humerus in anterior view; 6 , distal half of right tibia in anterior view. Scale bar $=3 \mathrm{~cm} .7-8$, Nematherium longirostris MPM-PV 19326. 7, anterior fragment of left dentary in lateral view (above) and oclusal view (below); 8 , upper molariforms in oclusal view (to the left) and lateral view (to the right). Scale bar $=1 \mathrm{~cm}$ 
topectoral shelf as observed in mylodontids, or the overall robustness typical of these sloths. The size and morphology of MPM-PV 19358 allow confident assignment to Planopinae, but its remains are not sufficiently well preserved for a more precise identification.

MyLOdONTIDAE Gill, 1872

Genus Nematherium Ameghino, 1887

Type species. Nematherium angulatum Ameghino, 1887. Santa Cruz Formation, Barrancas del Río Santa Cruz, Province of Santa Cruz, Argentina.

Nematherium longirostris Ameghino, 1891a

Figure 7.7-8, Table 1

Referred material. MPM-PV 19326, L dentary portion with mf1 alveolus, isolated upper teeth, and several skull fragments. Geographic occurrence. Segundas Barrancas Blancas (Ea. Cordón Alto), Río Santa Cruz, Province of Santa Cruz, Argentina. Stratigraphic occurrence. Santa Cruz Formation (Early-Middle Miocene).

Description. MPM-PV 19326 is an anterior portion of a $L$ dentary, with part of the symphysis, the mf1 alveolus, and the mesial part of the mf2 alveolus (Fig. 7.7), four upper molariforms, L Mf1 and Mf3-4 connected by bone, and R Mf2 (Fig. 7.8). The skull fragments are very small and not identifiable. Comments. The upper teeth of MPM-PV 19326 more closely resemble in form and size those of the type of Nematherium longirostris, MACN-A 4660 (a nearly complete skull for which Scott, 1904: pl. 63, fig. 3, illustrated only the palatal portion), than the type specimens of Analcitherium antarcticum (Scott, 1904: pl. 63, fig. 1a), Ammotherium aculeatum Ameghino, 1894 (see Scott, 1904: pl. 62, fig. 2a), Ammotherium declivum Ameghino, 1891a (see Scott, 1904: pl. 62, fig. 4a), and Lymodon perfectus Ameghino, 1891a (see Scott, 1904: pl. 62, fig. 1a). The dentary portion of MPM-PV 19326 is fragmentary and preserves the alveolus of cf 1 . It is probably of a young individual because the symphyseal suture is open. MPM-PV 19326 is assigned to N. longirostris for the reasons explained below.

\section{COMMENTARY ON AMEGHINO'S 1887 TAXA}

This section provides a brief account of Ameghino's (1887) taxa (type specimens) recorded from the Río Santa Cruz, including their descriptions, current taxonomic status, and figures when possible (Table 2). In the Discussion, we provide a historical and critical review of their taxonomy, focusing on the taxa for which the remains reported here allow critical observations on taxonomic and systematic issues regarding them.

\section{Schismotherium fractum Ameghino, 1887, p. 21}

The type specimen (an incomplete dentary, no record of the catalogue number) on which Ameghino (1887) erected this species was never figured, and Mones (1986, p. 250) indicated that it was lost. However, the specimen appears in Scott's album (Vizcaíno et al., 2017: Suppl. files, Appendix 1, p. 64, fig. 125d; Fig. 3.4), but it does not match Ameghino's $(1887,1889)$ descriptions. Recent efforts to find the holotype at the MLP collection were unsuccessful, so designation of a neotype was required to permit further systematic analyses. Racco et al. (2018) provided an extensive description of the events that occurred during the years that followed C. Ameghino's expedition to the Río Santa Cruz, including the destiny of the fossils collected. These authors designated MACN-A 6445-6470 as the neotype for the species Schismotherium fractum, a specimen that was recognized by Ameghino (1894, 1898) and illustrated by Scott (1904), and includes a complete skull and mandible, several vertebrae, and elements of the forelimb and hind limb.

\section{Eucholoeops ingens Ameghino, 1887, p. 21}

The designation of Eucholoeops ingens was based on a complete skull and mandible, largely covered by hard matrix, that was never figured, and for which there is no record of the catalogue number. Mones (1986, p. 248) indicated that it was housed at the MLP, but lost. Exhaustive searches for the original type specimen failed. New well-preserved remains of Eucholoeops recovered in the last 15 years by MLP-MACN-Duke University expeditions allowed De luliis et al. (2014) to provide a revision of the status of several species erected for Eucholoeops, focusing on E. ingens, and designated a neotype for the latter, MPM-PV 3401. 


\section{Eucholoeops infernalis Ameghino, 1887, p. 21}

The type of E. infernalis (MLP 4-7; Fig. 2.1-2) had not been previously figured, although it appears in Scott's album (Vizcaíno et al., 2017: Suppl. files, Appendix 1, p. 61, fig. 120), and identified as the type. It consists of the anterior part of a skull with left and right molariforms present but with their occlusal surface broken, and only the basal portion of the right Cf1, broken deeply within its alveolus, preserved. Ameghino's original diagnosis mentioned a cf1, but there are no associated mandibular remains. Fernicola (2011) noted that MLP 4-7 could not be located, but it has since been recovered. MACN-A 2095 is identified in MACN records as the type of $E$. infernalis, but this is incorrect as explained below in the Discussion.

\section{Eucholoeops adteger Ameghino, 1887, p. 21-22}

The type specimen of E. adteger (MLP 4-63; Fig. 2.3-4) is a left maxillary portion preserving Mf1-3, the mesial part of the Mf4 alveolus, and the distal part of the Cf1 alveolus of a very young individual, as evidenced by the open intermaxillary suture. The specimen had not been previously figured in the literature, but appears in Scott's album as the type of Hapalops adteger (Vizcaíno et al., 2017: Suppl. files, Appendix 1, p. 64, fig. 125c; Fig. 3.3). Ameghino (1891a) transferred the species to Hapalops, whereas Mercerat (1891) moved it to Eurysodon, based on the same specimen. Scott (1904, p. 258) synonymized it with Hapalops. MACN records indicate that MACN-A 4509, a right mandibular ramus, and MACN-A 4510, a left mandibular ramus, from the same individual comprise the type of this species (as Hapalops adteger), but this is not correct (see Table 2).

\section{Hapalops rectangularis Ameghino, 1887, p. 22}

The type specimen of $H$. rectangularis is lost (no record of the catalogue number at MLP). Ameghino (1889) noted that it included the posterior part of a left dentary, with a complete mf3 and the distal part of $\mathrm{mf2}$, but missing the coronoid and angular processes. He described this specimen, as well another, as the two specimens that represented this species. The second specimen was described as the posterior portion of the right dentary with $\mathrm{mf2}-3$ and part of mf1 (see Ameghino, 1889) The left dentary was figured by Scott (1903, p. 206, fig. 29) and appears (albeit as a poor image) in Scott's album (Vizcaíno et al., 2017: Suppl. files, Appendix 1, p. 64, fig. 125a; Fig. 3.1); it is identified as the type of $H$. rectangularis in both sources. MACN-A 2089 and MACN-A 2091 are identified as the type specimens of $H$. rectangularis in the MACN catalogue and in Mones (1986, p. 249).These remains, considered in more detail below, are clearly not so (see Table 2), and are among the remains that Ameghino came to consider as alternate types for several of the species he erected on material to which he no longer had access.

\section{Hapalops indifferens Ameghino, 1887, p. 22}

The type specimen (MLP 4-33, Fig. 2.7-8) is a right mandibular ramus preserving of1 broken below the level of the alveolar margin, the alveoli of mf1-mf2, and the partial alveolus of mf3. It is figured in Scott (1903, p. 208, fig. 31) and appears in his album (Vizcaíno et al., 2017: Suppl. files, Appendix 1, p. 64, fig.125f; Fig. 3.6). It is indicated as the type of this species in both sources. MACN records indicate that MACN-A 2093, a nearly complete skull, and MACN-A 2094, a right mandibular ramus belonging to the same individual as MACN-A 2093, comprise the type of this species; however, it is clear that this is incorrect (see Table 2).

\section{Hapalops ellipticus Ameghino, 1887, p. 22}

The type specimen (MLP 4-44; Fig. 2.5-6), is a partial left dentary preserving mf1-3, poorly preserved but with the section of these teeth intact. The specimen was figured by Scott (1903, p. 206, fig. 30) and appears in his album (Vizcaíno et al., 2017: Suppl. files, Appendix 1, p. 64, fig. 125b; Fig. 3.2), and indicated as the type in both sources. Scott (1903) synonymized this species with $H$. rectangularis. MACN records indicates that MACN-A 1089, a right mandibular ramus, is the type of $H$. ellipticus, but it is clearly not the original type (see Table 2).

\section{Trematherium intermixtum Ameghino, 1887, p. 22}

The type specimen (MLP 4-45; Fig. 2.9-10) is a partial left dentary preserving the alveolus of $\mathrm{mf} 2$, all but the lingual wall of the mf3 alveolus, and the distal part of the mf1 alveolus. It has never been figured, but appears in Scott's album and is noted as the type (Vizcaíno et al., 2017: Suppl. 
TABLE 2 - Taxonomic synopsis of Ameghino's (1887) sloth species ${ }^{1}$

\begin{tabular}{|c|c|c|c|}
\hline Species & Type specimen & Invalid types in MACN-A catalogue & Current status and references \\
\hline $\begin{array}{l}\text { Schismotherium } \\
\text { fractum }\end{array}$ & $\begin{array}{l}\text { Lost. No catalogue number at MLP. } \\
\text { Figured in Scott's album (Vizcaíno et al., } \\
2017 \text {; see Fig. 3.4, this work). }\end{array}$ & - & $\begin{array}{l}\text { Schismotherium fractum, Neotype } \\
\text { MACN-A 6445-70, Racco et al. (2018) }\end{array}$ \\
\hline $\begin{array}{l}\text { Eucholoeops } \\
\text { ingens }\end{array}$ & $\begin{array}{l}\text { Lost. No catalogue number at MLP. } \\
\text { Not figured. }\end{array}$ & - & $\begin{array}{l}\text { Eucholoeops ingens, Neotype MPM-PV } \\
3401 \text {, De luliis et al. (2014) }\end{array}$ \\
\hline $\begin{array}{l}\text { Eucholoeops } \\
\text { infernalis }\end{array}$ & $\begin{array}{l}\text { MLP 4-7, Fig. 2.1-2. Figured in Scott's } \\
\text { album (Vizcaino et al., 2017). }\end{array}$ & MACN-A 2095 & Hapalops infernalis Scott (1904) \\
\hline $\begin{array}{l}\text { Eucholoeops } \\
\text { adteger }\end{array}$ & $\begin{array}{l}\text { MLP 4-63, Fig. 2.3-4. Figured in Scott's } \\
\text { album (Vizcaino et al., 2017; } \\
\text { see Fig. 3.3, this work). }\end{array}$ & $M A C N-A 4509-10^{2}$ & Hapalops adteger Scott (1904) \\
\hline $\begin{array}{l}\text { Hapalops } \\
\text { rectangularis }\end{array}$ & $\begin{array}{l}\text { Lost. No catalogue number at MLP. } \\
\text { Figured by Scott (1903), in Scott's } \\
\text { album (Vizcaino et al., 2017; } \\
\text { see Fig. 3.1, this work). }\end{array}$ & MACN-A 2089, $2091^{3}$ & Hapalops rectangularis Scott (1903) \\
\hline $\begin{array}{l}\text { Hapalops } \\
\text { indifferens }\end{array}$ & $\begin{array}{l}\text { MLP 4-33, Fig. 2.7-8. Figured in Scott's } \\
\text { album (Vizcaino et al., 2017; } \\
\text { see Fig. 3.6, this work). }\end{array}$ & MACN-A 2093-94² & Hapalops indifferens Scott (1903) \\
\hline $\begin{array}{l}\text { Hapalops } \\
\text { ellipticus }\end{array}$ & $\begin{array}{l}\text { MLP 4-44, Fig. 2.5-6. Figured by Scott } \\
\text { (1903) and in Scott's album (Vizcaino } \\
\text { et al., 2017; see Fig. 3.2, this work). }\end{array}$ & MACN-A 1089 & Hapalops rectangularis Scott (1903) \\
\hline $\begin{array}{l}\text { Trematherium } \\
\text { intermixtum }\end{array}$ & $\begin{array}{l}\text { MLP 4-45, Fig. 2.9-10. Figured in } \\
\text { Scott's album (Vizcaino et al., 2017). }\end{array}$ & - & Edentata incertae sedis Scott (1904) \\
\hline $\begin{array}{l}\text { Nematherium } \\
\text { angulatum }\end{array}$ & $\begin{array}{l}\text { Lost. No catalogue number at MLP. } \\
\text { Not figured. }\end{array}$ & - & Nematherium angulatum Scott (1904) \\
\hline $\begin{array}{l}\text { Nematherium } \\
\text { sinuatum }\end{array}$ & $\begin{array}{l}\text { Lost. No catalogue number at MLP. } \\
\text { Not figured. }\end{array}$ & - & Nematherium angulatum Scott (1904) \\
\hline $\begin{array}{l}\text { Planops } \\
\text { longirostratus }\end{array}$ & $\begin{array}{l}\text { Lost. No catalogue number at MLP. } \\
\text { Figured in Scott's album (Vizcaino } \\
\text { et al., 2017; see Fig. 3.5, this work). }\end{array}$ & MACN-A 4637 & Planops longirostratus Scott (1904) \\
\hline $\begin{array}{l}\text { Xyophorus } \\
\text { rostratus }\end{array}$ & $\begin{array}{l}\text { Lost. No catalogue number at MLP. } \\
\text { Figured in Scott's album (Vizcaíno } \\
\text { et al., 2017). }\end{array}$ & - & Hapalops rostratus Scott (1904) \\
\hline $\begin{array}{l}\text { Xyophorus } \\
\text { simus }\end{array}$ & $\begin{array}{l}\text { Lost. No catalogue number at MLP. } \\
\text { Figured in Scott's album (Vizcaíno } \\
\text { et al., 2017). }\end{array}$ & $\begin{array}{l}\text { MACN-A 6417, } \\
\text { MACN-A } 4636\end{array}$ & Hapalops rostratus Scott (1904) \\
\hline $\begin{array}{l}\text { Entelops } \\
\text { dispar }\end{array}$ & $\begin{array}{l}\text { Lost. No catalogue number at MLP. } \\
\text { Not figured. }\end{array}$ & - & Edentata incertae sedis Scott (1904) \\
\hline
\end{tabular}

${ }^{1}$ See text for further information. ${ }^{2} \mathrm{MACN}$ records indicate that these specimens belong to the same individual. ${ }^{3} \mathrm{MACN}$ records indicate that these specimens are probably from the same individual, as are MACN-A 2090 and 2092 (which, however, are not indicated as types).

files, Appendix 1, p. 66, fig.131e, and Appendix 2: p. 62, respectively). Mercerat (1891) considered it as Schismotherium intermixtum, which Scott (1904, p. 326) in part synonymized with Trematherium intermixtum. Scott (op. cit., p. 358-359) considered this species as Edentata incertae sedis.

\section{Nematherium angulatum and N. sinuatum Ameghino,} 1887, p. 22-23

The type specimens of $N$. angulatum and $N$. sinuatum are lost, as indicated by Mones (1986, p. 257), and there is no record of the catalogue numbers at MLP. They were never 
figured, and do not appear in Scott's album (Vizcaíno et al., 2017: Suppl. files, Appendix 1, 2). Ameghino's (1887) description of $N$. angulatum recognized a greater resemblance of its molarifoms to those of Mylodon than to those of the genera he had previously described; i.e., that at least some molariforms were lobated. Mf2 was considered "eliptico-cilindrica;" Mf3-4 triangular; and mf4 bilobate, with the mesial lobe smaller than the distal. Nematherium sinuatum was described as slightly larger than $N$. angulatum, and with mf4 large, angular, and bilobate on its vestibular surface (i.e., its vestibular surface bore an apicobasal sulcus), and the mesial lobe shorter but wider than the distal.

In addition to Nematherium angulatum and $N$. sinuatum, two other species were erected, N. longirostris Ameghino (1891a, p. 324) and N. lavagnanum Mercerat (1891, p. 26). Scott (1904) synonymized these last three species with $N$. angulatum. Further, this author also recognized additional species of Nematherium (e.g., N. auca Ameghino, 1891a, N. profundatum, $N$. declivum; these species were originally described under Ammotherium and Lymodon) and provisionally recognized Analcitherium. Given that the remains of these taxa have not been critically revised since Scott's (1904) work (the efforts of Simpson, 1941, and Bordas, 1939, resulted only to further increase the number of Nematherium species) and that the original type of Nematherium is lost and was never figured, we retain $N$. longirostris pending a systematic revision.

\section{Planops longirostratus Ameghino, 1887, p. 23}

The type specimen of $P$. longirostratus is lost, as indicated by Mones (1986, p. 253), and there is no record of the catalogue number at MLP. It has been never figured, but it appears in Scott's album as the type (Vizcaíno et al. 2017: Suppl. files, Appendix 1, page 64, fig.125e; Fig. 3.5). Ameghino's (1887) description of the specimen indicates that Mf1, separated from Mf2 by a short diastema, was elliptical, with its major axis aligned with the long axis of the tooth row, and obliquely worn. The palate extended well beyond Mf1, producing an elongated rostrum. Ameghino (1889) noted that the species was known only from a fragment of a right maxilla, including the Cf1 and part of the Mf1 alveolus, which coincides precisely with the image in Scott's album, noted above. Carlini et al. (2013: fig. 7C) provided an illustration of a specimen, claiming that is was the "holotype of Planops longirostratus (no catalogue number)." Their illustration, however, is of an anterior part of a skull in palatal view, with a complete dentition, that does not match Ameghino's (1887) original description and, therefore, it is not the type specimen. The specimen illustrated in Carlini et al. (2013: fig. 7C) is AMNH 9302, which was illustrated by Scott (1904: pl. 59, fig. 1a).

MACN-A 4637 is catalogued as the type of Planops longirostratus. This specimen is a right maxilla of a juvenile individual and preserves Cf1, Mf1, the alveolus of Mf2, and Mf2-4. It does not match the descriptions of Ameghino (1887, 1889), and was recovered by C. Ameghino from KillikAike, a coastal locality along the Río Gallegos, in 1890-1891; it is thus not the original type and MACN records should be altered to reflect this.

\section{Xyophorus rostratus and X. simus Ameghino, 1887, p. 23}

The type specimens of $X$. rostratus and $X$. simus are lost, as indicated by Mones (1986, p. 251), and there is no record of the catalogue numbers at MLP. They have been never figured, but appear in Scott's album, $X$. rostratus as the type (Vizcaíno et al., 2017: Suppl. files, Appendix 1, p. 66, fig. 131c), and $X$. simus not indicated as the type (Vizcaíno et al., 2017: Suppl. files, Appendix 1, p. 9, fig. 14a, and p. 66, fig. 131d). Xyophorus rostratus appears as a mandibular fragment with one tooth, but the fragmentary nature of the specimen and poor quality of the image preclude any interpretation; $X$. simus is represented by the anterior portion of a skull (p. 9, fig. 14a) and a small mandibular fragment (p. 66, fig. 131d). They are not identified as types and do not match Ameghino's original description. MACN records indicate MACN-A 6417 and MACN-A 4636 as type specimens of $X$. simus, but this is incorrect (see Table 2), as explained in more detail below.

\section{Entelops dispar Ameghino, 1887, p. 23}

The type specimen of $E$. dispar is lost, as indicated by Mones (1986, p. 245), and there is no record of the catalogue number at MLP. Ameghino (1889, p. 654) described but did not figure it. Scott (1904, p. 360) did not describe it and only listed it under Edentata incertae sedis. This enigmatic taxon has received scant attention, but only in part 
due to the early loss of its type and only specimen and the absence of any visual reference: Ameghino's $(1887,1889)$ descriptions presented characteristics that were decidedly odd for a sloth. Pascual's (1961) description of Entelops parodii, based on MLP 58-V-21-1, verified these odd characteristics. The dentary of the latter carried ten teeth arranged to form a closed dental arcade. The distal three were bilobate in section, whereas those nearer the front of the dentary were apparently peg shaped and some possibly incisiform (see Hoffstetter, 1982; Pujos and De luliis, 2007). However, the status of Entelops as a sloth was and remains uncertain. It has been considered both a possible candidate as a basal sloth (see Pujos and De luliis, 2007) and dubiously a sloth at all (Hautier et al., 2016). On a positive note, the concern expressed by Pujos and De luliis (2007) over the possible loss as well of the type of $E$. parodii was premature - the specimen has recently been rediscovered in MLP.

\section{DISCUSSION}

\section{TAXONOMIC RICHNESS OF SANTACRUCIAN SLOTHS}

In order to review the taxonomic richness of Santacrucian sloths, we evaluate the new remains reported here with those described by Ameghino (1887), and then compare them with other remains recently recovered from localities from the eastern coastal area of the Province of Santa Cruz (e.g., between Ríos Coyle and Gallegos; Bargo et al., 2012; Kay et al., 2012) and from the western region (e.g., Lago Posadas= Pueyrredón; Cuitiño et al., 2019b).

Ameghino (1887) described 14 species from Río Santa Cruz localities (see above), of which only Schismotherium fractum and Eucholoeops ingens were recently reviewed and considered valid (Racco et al., 2018 and De luliis et al., 2014, respectively). The remaining species have not been critically reviewed since Scott $(1903,1904)$, as noted above (and see the discussions below). Whereas we are able to

TABLE 3 - Taxonomic richness of Santacrucian sloths: comparison of the Río Santa Cruz taxa with other localities recently studied

\begin{tabular}{|c|c|c|c|c|c|}
\hline \multirow{2}{*}{ Taxa } & & \multicolumn{2}{|c|}{ Río Santa Cruz (this article) } & \multirow{2}{*}{$\begin{array}{c}\text { Eastern coastal } \\
\text { localities }^{1}\end{array}$} & \multirow{2}{*}{ Lago Posadas ${ }^{2}$} \\
\hline & & $B B$ & $S B B$ & & \\
\hline \multirow[t]{2}{*}{ Megalonychidae } & Eucholoeops fronto & & & $x$ & \\
\hline & Eucholoeops ingens & & & $x$ & \\
\hline \multirow[t]{10}{*}{ Megatherioidea } & Hapalops sp. & $x$ & $x$ & $x$ & $x$ \\
\hline & cf. Hapalops & $x$ & $x$ & & $x$ \\
\hline & Hapalops $c f$. elongatus & $x$ & $x$ & & \\
\hline & Hapalops platycephalus & & & & $\mathrm{x}$ \\
\hline & Hapalops gracilidens & & & & $x$ \\
\hline & Pelecyodon cristatus & & & $x$ & \\
\hline & Hyperleptus garzonianus & & & $x$ & \\
\hline & Schismotherium $c f$. fractum & & $x$ & & \\
\hline & Xyophorus atlanticus & & $x$ & & \\
\hline & Megatherioidea indet. & $x$ & $x$ & & $x$ \\
\hline \multirow[t]{2}{*}{ Megatheriidae } & Planopinae indet. & & $x$ & & \\
\hline & Megatheriidae indet. & & $x$ & & \\
\hline \multirow[t]{3}{*}{ Mylodontidae } & Nematherium longirostris & & $x$ & & \\
\hline & Nematherium sp. & & & $x$ & \\
\hline & Mylodontidae indet. & $\mathrm{x}$ & & & \\
\hline
\end{tabular}

${ }^{1}$ Bargo et al. (2012), and Kay et al. (2012). ${ }^{2}$ Cuitiño et al. (2019b) 
assign with some degree of confidence the remains reported here to only one, Schismotherium cf. fractum (MPM-PV 19328; Fig. 5.4), of Ameghino's (1887) species, our generic level assignments are broader. Of Ameghino's (op. cit.) eight described genera (Schismotherium, Eucholoeops, Hapalops, Trematherium, Nematherium, Planops, Xyophorus, and Entelops) we are able to recognize four: Schismotherium, Hapalops, Nematherium, and Xyophorus. As will become clear from the descriptions and discussions below, the inability for providing more confident and complete identifications at both the generic and species levels is due largely to the unstable taxonomy and systematics of these sloths. We report here remains of Xyophorus atlanticus (MPM-PV 19337; Fig. 6), based on near-identical morphologic and metric resemblance to the type of this species, MACN-A 4631. Similarly, we also report Nematherium longirostris (MPM-PV 19326; Fig. 7.6). These species were not described from Río Santa Cruz by Ameghino (1887). At a higher level, we record the presence of Planopinae, although we are unable to verify whether the remains belong to Planops.

Table 3 lists the taxa recovered from the Río Santa Cruz localities, as well as those reported by Bargo et al. (2012) and Kay et al. (2012) from four Atlantic coastal localities: Anfiteatro, Estancia La Costa, Cañadón Silva, and Puesto Estancia La Costa; and by Cuitiño et al. (2019b) from Lago Posadas (see Fernicola et al., 2019: figs. 1 and 5). The coastal localities (although these contain additional remains that have not yet been analyzed) yielded three genera and four species (Eucholoeops ingens, E. fronto, Pelecyodon cristatus and Hyperleptus garzonianus) not present in our collection, although Eucholoeops is recorded from the Río Santa Cruz, as reported by Ameghino (1887). The two regions (coastal localities and Río Santa Cruz) do share the presence of Hapalops and Nematherium. A notable difference is the presence of megatheriids (that is, large-sized sloths) from the Río Santa Cruz.

Our Río Santa Cruz localities and Lago Posadas share the presence of Hapalops. Likewise notable is the absence of large-sized sloths in Lago Posadas, although the total sample is much smaller.

\section{CRITICAL TAXONOMIC REVIEW AND FURTHER CON- SIDERATIONS}

Scott's $(1903,1904)$ decisions largely suggest that he broadly accepted Ameghino's $(1887,1889)$ concepts of the genera as initially established from the fossil remains that Ameghino (1887, see Tab. 2) described and reinforced by material subsequently recovered from the Santa Cruz Formation by his brother C. Ameghino. The inclusion of these additional remains and F. Ameghino's lack of access to his original specimens introduced confusion over which specimens were being considered as he continued to develop and refine his concepts of the taxa first established in 1887, as explained in the following paragraphs.

As is well known, F. Ameghino's relationship with the MLP deteriorated to such an extent that he was denied access to many of the remains on which he had established the taxa under consideration (as well as of other taxa; see Fernicola, 2011). Because of these circumstances, Ameghino's (e.g., 1889, 1891a, 1894) subsequent work, including the further development of his concepts of $H$. rectangularis and other Santacrucian sloths, relied on additional specimens collected by Carlos. Several of them were considered by Florentino (as recorded in the MACN catalogue) as alternate types for species based on material that he could no longer access (an example is noted above). Although these remains were important to Ameghino's further understanding of the Santacrucian sloths erected in 1887, it is worth keeping in mind that they were collected from different localities; that is, not from localities along the Río Santa Cruz, but from coastal localities. In addition to this, a large proportion (9 out of 14 ) of the 1887 type specimens are currently lost (Table 2), as explained below.

Scott's $(1903,1904)$ decisions with regard to the sloths erected by Ameghino (1887; 1891a, b; 1894) have come to represent the modern concept of the Santacrucian sloths, but it was clear then and remains so today that there are many more taxa than can be justified based on the available remains. Without improved resolution of the taxonomic issues, other aspects of the paleobiology (for example, the paleoecological context) of these sloths (and indeed of the Santacrucian fauna) cannot be reliably considered at the species and, albeit to a lesser degree, generic levels. However, Scott's taxonomic and systematic actions have largely 
been accepted uncritically (in stark contrast, we might add, to Ameghino's actions), and this, we suggest, has contributed in no small degree to the unsatisfactory understanding of these sloths. Given this state of affairs, it is worth considering whether Scott's actions should be laxly maintained or rigorously reconsidered.

While resolving the taxonomic and systematic issues is beyond the scope of this paper (this would require considerable morphological and metric analyses of the many specimens beyond those that were initially used to erect the taxa), we offer paths towards resolution for several of the genera first established by Ameghino (1887) by identifying contentious taxonomic and systematic issues, and by framing the questions that need to be addressed in order to reach robust decisions. Certainly, several of the taxonomic actions that must be made will involve arbitrary decisions (for example, on choice of neotypes; there is no other way out of the impasse), but this is acceptable provided that the decisions are justified based on rigorous argumentation and analyses.

\section{Hapalops and Eucholoeops}

These genera are discussed together because the taxonomic history of several of their species is intertwined, and it becomes difficult to discuss the one without numerous references to the other.

Ameghino (1887) erected Hapalops rectangularis, and described it as possessing four lower teeth, with the first tooth being small and caniniform in shape. Ameghino (1889, p. 686, translated from the original by the authors) noted that this species "is represented by two mandibular fragments, the posterior part from the left side, preserving the two last molars, and the posterior part from the right side, preserving the last two molars and part of the antepenultimate molar." From this, it is evident that neither specimen preserved the first (or most mesial) tooth. The left dentary was recognized as the type and as housed in MLP by Scott (1903: fig. 29; Vizcaíno et al., 2017; Fig. 3.1), and is considered lost; this specimen matches Ameghino's (1889) description of the partial left dentary. The identity of the right side dentary is unknown, and to our knowledge has not been mentioned since. The type specimen, however, did not match Ameghino's (1887) original description, in the sense that it was insufficiently preserved to have served this purpose, as was noted by Mercerat (1891); Ameghino (1887) could not have determined the form of the anteriormost tooth, which was described as caniniform in shape, from the type specimen. Indeed, Ameghino (1889) made no mention of a caniniform tooth in the description of $H$. rectangularis, but his generic description of Hapalops indicates the presence of a small, more or less cylindrical first tooth, separated from the remaining teeth (i.e., a diastema was present, Ameghino, op. cit.).

Even though $H$. rectangularis is the type species of Hapalops, Scott (1903, p. 206) clearly recognized the inadequate nature of the type specimen of the species: "unfortunately, this fragment is uncharacteristic and might belong to any one of several species" of Hapalops. Nonetheless, Scott (1903, p. 206) saw fit to use AMNH 9222 as a proxy for this specimen, noting that it "is an excellently preserved mandible... with all the teeth in place, which agrees very clearly with the corresponding portion of the type and is probably referable to the same species." Scott (1903) then described this species based on AMNH 9222, and further noted that $H$. rectangularis is also distinguished on astragalar morphology, based on the astragalus of AMNH 9222. However, as this author himself noted, this depends on the correct association of the astragalus (and calcaneum) with the mandibular remains, and this association is not certain.

Ameghino (1887) erected two other Hapalops species, $H$. indifferens (MLP 4-33; Fig. 2.7-8) and H. ellipticus (MLP 4-44, Fig. 2.5-6). Given the similarity among the homologous portions of the three type specimens, it becomes evident that Ameghino (1887) likely proceeded by recognizing them as congeneric but as specifically distinct, and generically distinct from other sloth remains recovered from localities along the Río Santa Cruz. This would explain Ameghino's (1887) reference to a caniniform-like tooth in $H$. rectangularis despite the lack of appropriate material for this characterization to have been made (i.e., based on Ameghino's 1889 descriptions, neither specimen known for $H$. rectangularis preserved a caniniform tooth or its alveolus), and Ameghino's (1889) formal presentation of a generic diagnosis for Hapalops. That is, Ameghino (1887) deduced the presence of a caniniform tooth in $H$. rectangularis (and $H$. ellipticus) based on its presence in a species, $H$. indifferens, 
which he considered congeneric with it.

Scott (1903, p. 206) synonymized $H$. ellipticus (as well as Mercerat's, 1891, Schismotherium rectangularis and Lydekker's, 1894, Eucholoeops ingens, in part) with $H$. rectangularis, although he offered no rigorous justification for this synonymy. As noted above, he supplemented the description of the species with AMNH 9222. Conversely, Scott (1903) maintained $H$. indifferens as a distinct species, but he did not provide justification for this decision based on the original type of this species: there is no attempt at comparison with the type of $H$. rectangularis or, for that matter, of $H$. ellipticus. Instead, he noted that the nearly complete mandible of YPM-VPPU 15110 (which also includes the anterior half of a skull with dentition preserved) is assignable to $H$. indifferens, and then proceeded to characterize the species based entirely on this specimen.

Ameghino (1887) erected three species of Eucholoeops: E. ingens, E. infernalis, and E. adteger. As noted above in Commentary on Ameghino's 1887 Taxa, E. ingens and several related species of Eucholoeops subsequently named by Ameghino (1891a, 1894) were treated by De luliis et al. (2014). The other two, E. infernalis and E. adteger, were subsequently transferred to Hapalops (Scott, 1904). Ameghino (1889, p. 694) considered E. infernalis as slightly smaller than $E$. ingens, based on the anterior part of a skull, with palate and dentition, "bastante destrozada [considerably destroyed or damaged]" and several maxillary fragments and isolated teeth. The partial skull is MLP 4-7 (Fig. 2.1-2), but the identity of the other remains is not known. Mf1 to Mf3 of MLP 4-7 are mesiodistally elongated, producing a nearly squared section.

Ameghino (1889, p. 694, pl. 34, figs. 9) illustrated MACNA1061, the anterior part of a skull that closely resembles MLP 4-7, as E. infernalis. Although poorly preserved, its molariform alveolar sections are nearly squared, as in MLP 4-7. Ameghino (1894) maintained this species in Eucholoeops, but this decision may have been based on a different specimen, MACN-A2095 (see below). Mercerat (1891, p. 23) transferred it to Eurysodon infernalis. Lydekker (1894, pl. 59, figs. 1, 1a) illustrated a partial skull as Pseudhapalops infernalis, but this is not any of those noted here. Scott (1904) transferred Ameghino's (1887) E. infernalis (and Lydekker's 1894 Pseudhapalops infernalis) to Hapalops. Scott (op. cit., p.
238-239) noted that the type specimen "is in a much damaged condition, but apparently indicates a species different from any of the preceding representatives of Hapalops," but the only features explicitly noted are that the molariform teeth were relatively long mesiodistally and the "preorbital fossae of the maxillaries are unusually deep." MACN-A 2095 is identified in MACN records as the type of $E$. infernalis. This specimen is another of those that Ameghino selected as an alternate type for one of his species, but has not been considered in the literature (see below).

The remains on which $E$. adteger is based include at least a partial left maxilla (MLP 4-63; Fig. 2.2-3). Ameghino (1887) did not identify these remains explicitly but provided characters from these elements. Ameghino (1889) indicated that the species was known from a left partial maxilla, preserving the first three molariforms and partial Cf1 and Mf4 alveoli, a fragment of a right maxilla, preserving mf1 and $\mathrm{mf2}$, and the anterior portion of a left dentary, preserving cf1 and part of the mf1 alveolus. Ameghino (1889: pl. 34, fig. 7) illustrated the left mandibular fragment, and retained the species in Eucholoeops, but considered that it might belong to a distinct genus. Ameghino (1891a, p. 317) transferred it to Hapalops (although the former genus is misspelled: "Hapalops adteger. = Encholoeops adteger, Amegh., 1887"). Mercerat (1891, p. 18) transferred Ameghino's species to his new genus Eurysodon. The latter author in effect followed Ameghino's (1889) opinion, but created a new genus to receive, in part, Ameghino's Eucholoeops adteger, in contrast to Ameghino's (1891a) transfer of the species to Hapalops. However, it may be conjectured that Mercerat (1891) was likely unaware of Ameghino's (1891a) action in time to have addressed it in his own publication: Ameghino (1891c; 1894) noted that Ameghino (1891a) and Mercerat (1891) appeared and were distributed as offprints during the first half of August, 1891, and second half of August, 1891, respectively. Mercerat (1891) only considered the left maxilla (the type, MLP 4-63; see above) as belonging to the species, and erected the new species Eurysodon boulei for reception of Ameghino's two other specimens.

A start to resolving the issues regarding Hapalops requires an understanding of the main differences that are apparent among Santacrucian sloths. Among those in which the most mesial tooth is caniniform and separated by a dis- 
tinct diastema from the remaining molariform cheek teeth (that is, none of these are relatively simple, slender, and apicobasally curved), three dental patterns are apparent. These patterns are recognizable based on subsequently recovered and more complete remains than those reported on by Ameghino (1887, 1889). In one pattern, present in Eucholoeops, the caniniform tooth is large and tends to be triangular in section, and the molariform teeth, except for the distal lower, tend to be transversely expanded and elliptical; that is, the corners of the teeth are rounded. The other two patterns typically occur in species that have been attributed to Hapalops. These two patterns are similar in that the caniniform tooth is smaller and tends to be circular or oval in section and the molariform teeth tend to have angular corners, again except for the distal lower cheek tooth. In one pattern the teeth are more nearly squared (e.g., $H$. infernalis) and in the other the teeth appear more rectangular (that is, somewhat transversely expanded, as in e.g., $H$. elongatus and $H$. longiceps). Within this last group (i.e., with rectangular molariforms) a distinction is apparent in the length of the symphyseal spout: in the type of $H$. longiceps (YPM-VPPU 15523) the spout, about equal to the length of the lower tooth row, is decidedly longer than in $H$. elongatus (e.g., YPM-VPPU 15597), in which the spout is shorter than the lower tooth row length. These differences suggest the existence of two dental morphotypes, more nearly squared vs. rectangular cheek teeth, and within the latter a difference in symphyseal spout length. It should be noted that this difference is exaggerated in Scott (1903: pl. 32, fig. 1) because the illustration of the mandible of $H$. longiceps is inaccurate with regard to the length of the symphyseal spout: it is depicted as longer (decidedly more so than the lower tooth row length) than it actually is.

The remains from the Río Santa Cruz localities provide evidence that supports the presence of the two dental Hapalops morphotypes. In one the molariforms are relatively squared (the type of E. infernalis) and in the other relatively rectangular (MPM-PV 19318, $\mathrm{H}$. cf. elongatus). The relatively squared morphotype also occurs in the type of $H$. ponderosus (YPM-VPPU 15520), and the rectangular morphotype in the type of $H$. longiceps (YPM-VPPU 15523). The significance of such differences has not been assessed. It may be that many of the specimens subsequently attributed to Hapalops (as by Scott, 1903, 1904) all represent a single species, but this conclusion would ignore the demonstrable difference of the Hapalops morphotypes based on dentition and mandibular spout length, as just noted.

Given the degree of confusion that persists over the taxonomy and systematics of Hapalops, we suggest that Scott's actions require rigorous reassessment. Three such actions are related to the nature of the type specimen of $H$. rectangularis: 1 ) recognition of $H$. rectangularis as a valid zoological (as opposed to nomenclatural) entity; 2) assignment of AMNH 9222 to $H$. rectangularis; and 3) synonymy of $H$. ellipticus with $H$. rectangularis.

It is clear that the type specimen of $H$. rectangularis is inadequate for diagnosis, but $H$. rectangularis is a valid name and cannot be easily dismissed (see below). Scott's (1903) comment, noted above, that it could belong to several species, was presumably meant to include other species of Hapalops. However, the only clearly identifiable portion is m4, which is nearly circular (though slightly deformed) with its major axis set obliquely to the long axis of the tooth row, a morphology that is essentially identical with that of other species identified as Hapalops, as well as that of Eucholoeops ingens (see De luliis et al., 2014: fig. 6A) and Schismotherium fractum (see Racco et al., 2018: fig. 2.1). Indeed, Mercerat (1891) made this very observation and considered $H$. rectangularis as a synonym of $S$. fractum. It is a vexing question indeed as to why Scott (1903), who so obviously considered the original type of $H$. rectangularis inadequate for diagnosing the species, let alone the genus, would have chosen to maintain this species with the aim of retaining and assigning other (including new) species to the same genus. An adequate diagnosis has not, to our knowledge, ever been published for Hapalops, and based on the utterly inadequate nature of the type specimen of the type species, it would be most unlikely that a diagnosis could be provided. For this reason, it is critical that a reasonable solution be found that promotes stability in nomenclature. As the type specimen cannot stand as an objective standard of reference, Scott's (1903, 1904) assignment of AMNH 9222 and synonymy of $H$. ellipticus cannot be readily maintained based on this author's reasoning. Given the ambiguity of the type and concept of $H$. rectangularis, retention of this species does not appear to offer any taxonomic or system- 
atic advantages, barring perhaps the possibility that at least many of the numerous subsequently recovered remains (i.e., species) recognized currently as Hapalops based on Scott $(1903,1904)$ are conspecific. However, this seems highly unlikely, given the differences in Hapalops morphotypes noted above. If conspecificity were the case, it would render the matter trivial, and the justification for retaining the name could then indeed be that it is the type species of Hapalops, effectively following Scott (1903). However, the decision is not straightforward, given Scott's $(1903,1904)$ actions. The appropriate (we might even say, correct) action, in 1903, would have been to restrict the genus Hapalops to $H$. rectangularis (thus recognizing that it was a valid name) but, given its inadequate type, refer other species to other known or new genera. This would have had the advantage of isolating $H$. rectangularis. However, we are now more than 100 years beyond this, and Hapalops has become well known and accepted, and there is advantage in retaining it for stability in nomenclature.

A possible solution is to retain $H$. rectangularis, in acknowledgement of Scott's role as first reviser (see De luliis et al., 2014). The chain of procedure would then be to designate a neotype. There are at least two possible candidates: AMNH 9222 (a complete mandible), and MACN-A 2089-2092 (including the remains attributed by MACN records as probably belonging to the same individual, but only 2089, a right mandibular ramus, and 2091, a complete skull that cannot be located, are listed as type specimens; 2090 is a left mandibular ramus and 2092 includes postcranial remains (e.g., atlas, phalanges)). In choosing between them, a decision would need to consider the degree to which 1) Scott's role as first reviser should be maintained (the species is currently known on Scott's (1903) description of AMNH 9222), and 2) Ameghino's influence on the concept of the species should be considered, as this author choose the MACN remains as alternate types for his concept of the species. If the first consideration is deemed more appropriate, then the neotype would be AMNH 9222; if the second, then MACN-A 2089-2092. Once a decision is reached the second specimen must be compared with the first to evaluate whether the former is conspecific with the latter. A cursory comparison suggests that they are not. In AMNH 9222 the lower molariforms tend to be transversely wide, whereas in MACN-A 2089 and 2090 they tend to be more squared, strongly resembling the specimens that Scott (1904, pl. 40, figs. 2-4) assigned to H. elongatus (YPMVPPU 15155, 15597, and 15531). A complicating issue is that MACN-A 2089 and 2090 strongly resemble MLP 4-33, the type of $H$. indifferens, in size, section of the teeth, and the oval and obliquely oriented alveolus of cf1; it would appear that these two sets of remains are almost certainly conspecific.

There is also the question of Scott's (1903) synonymy of $H$. ellipticus with $H$. rectangularis. Although there may be little reason to doubt this synonymy, given the minor metric and morphological differences apparent between the two specimens, neither is there reason to accept it -there is no objective way of evaluating this decision due to the insufficient preservation of the type of $H$. rectangularis. Further, it is not clear that the type of $H$. ellipticus represents Hapalops, as $\mathrm{mf} 2$ is oval in section.

Scott's methods of reasoning in his recognition of $H$. indifferens, in contrast to his synonymy of $H$. ellipticus with $H$. rectangularis, requires scrutiny. It is clear, on the one hand, that this author was willing to accept individual variation, but his application of this criterion was inconsistent. For example, there was no hesitation in synonymizing $H$. ellipticus with $H$. rectangularis despite minor metric differences; on the other hand, he was willing to assign YPM-VPPU 15110 to $H$. indifferens despite a "remarkable" difference in position of the mental foramen, a difference that Scott (1903, p. 208; pl. 34, figs. 1-5) regarded as "doubtless individual merely."

However, the solution of recognizing and retaining $H$. rectangularis as the type species of Hapalops is problematic for the following reasons. The description of the species given by Ameghino (1887) cannot have been based on the type -it was simply not sufficiently complete for Ameghino to have drawn the characters indicated from it; the "diagnostic" features were drawn from other specimens that Ameghino erected as species that he considered congeneric with the type of $H$. rectangularis (as alluded to above, this is the most plausible explanation for Ameghino's actions, although it is not demonstrable). However, Ameghino's actions (for whatever reasons) were inappropriate: he could not have made this decision on sufficient information, given 
the nature of the type specimen. If we choose to accept $H$. rectangularis (and therefore Hapalops), our decision would be based ultimately on Scott's willingness to recognize it, based in turn on his acceptance of Ameghino's decision to recognize it as congeneric with remains assigned to other species of Hapalops. While a possibility, we maintain that this choice requires ignoring or overlooking the fact that it can never be objectively demonstrated -in other words, as we cannot test its accuracy (because we cannot know what $H$. rectangularis is), acceptance of $H$. rectangularis would undermine accuracy and objectivity in science.

In our opinion, we would do better to reject $H$. rectangularis, but attempt to salvage Hapalops -this would maintain a very well-known genus, thus promoting nomenclatural stability. There are several avenues for rejection that may be explored, including considering $H$. rectangularis a nomen $d u-$ bium, species inquirenda, or nomen vanum. A nomen dubium is defined by the International Code of Zoological Nomenclature (ICZN, 1999) as a name of unknown or doubtful application. Although this applies to $H$. rectangularis (a name of doubtful application), Mones (1989) noted that the scope of this term allows for the possibility or even probability that its status will be elucidated. However, it should be clear from the preceding discussion that this would be highly unlikely for this species. Species inquirenda is defined by the Code as a species of doubtful identity needing further investigation. Similar to the argument just made for nomen dubium, it is highly unlikely that further investigation could be expected to elucidate the identity of $H$. rectangularis. Nomen vanum ("empty name") is not included in the ICZN but is one of many terms used by zoologists (see, for example, Mones, 1989; Dubois, 2010). Simpson (1945) applied this term to names for which the proper application cannot be determined, although they otherwise fulfill the requirements of the rules of nomenclature. As explained more fully by Simpson (1948), such names are not known to be valid and cannot be applied to any specimens besides the type or syntypes; in this sense they may have a standing in nomenclature, but not in zoology, and it is unlikely (even though it may be conceivable) that such names can be validated by future work. Mones (1989) noted that a component of a nomen vanum is poorness of the type specimen.

A designation of nomen vanum would seem to best fit the circumstances of $H$. rectangularis, particularly as the type, besides being a poor specimen, is lost. We suggest that this proposal be elevated to the Commission for rejection of $H$. rectangularis as the type species, and another species, preferably one of the others originally assigned by Ameghino (1887) to Hapalops, be designated as the type species of the genus. Of the two other species, $H$. indifferens and $H$. ellipticus (the type specimens of which are still available at MLP), it should be clear from the discussions above that $H$. indifferens is by far the better choice in serving for formulating a diagnosis of Hapalops, as its type is more complete and its features are those that have come to be recognized as characteristic of Hapalops. This proposal would "solve" the problem of $H$. rectangularis, while saving Hapalops, thereby stabilizing nomenclature. This would be preferable to, for example, reviving a junior synonym or naming a new genus.

The type of E. infernalis is MLP 4-7, as indicated above. Scott (1904) noted the relatively long mesiodistal dimension of the molariform teeth, but did not mention MACNA1061, the specimen that Ameghino (1889) illustrated, which resembles the type in molariform shape. Neither did Scott (1904) mention MACN-A 2095, which appears in MACN records as the type of $E$. infernalis. This specimen, also the anterior part of a skull, is presumably the specimen on which Ameghino settled on as a basis for his concept of E. infernalis. However, the molariforms, mesiodistally compressed, are approximately oval in section and the caniniform is approximately triangular. These are features characteristic of Eucholoeops. Indeed, it may offer an explanation for Ameghino's (1889, 1894) continued retention of this species in Eucholoeops, whereas Scott (1904), likely based on the original type MLP 4-7, transferred the species to Hapalops. In any event, it is clear that MLP 4-7 is the type of the species and MACN records should be corrected in this regard.

\section{Xyophorus}

Ameghino (1887) erected Xyophorus rostratus and $X$. simus. This author described the former as possessing a horizontally worn, small, and approximately cylindrical ("elíptico cilíndrica") first lower tooth, separated from the remaining teeth by a diastema (although Ameghino did not 
consider it caniniform), and a short symphysis. These features were considered by Scott (1904, p. 239) as indicative of individuals of Hapalops. Xyophorus simus was distinguished by Ameghino (1887) as being twice the size of $X$. rostratus, with a shorter and stronger (more steeply tapered) symphyseal spout, and a completely cylindrical first lower tooth, which was also identified as a "muela" (cheek tooth or molariform) rather than a caniniform. It is unclear why Ameghino (1887) did not consider the first tooth as caniniform, but presumably he was influenced by aspects of its wear pattern as noted in Ameghino (1889).

Ameghino (1889) expanded the descriptions of these species. Xyophorus rostratus was represented by the anterior part of a left dentary, preserving the first tooth and symphyseal spout and part of the alveolus of the second tooth. The diastema was very short, very nearly the same length as the mesiodistal length of the first tooth. Of the second tooth, Ameghino (op. cit.) was only able to note that it was much larger than the first, but that its form could not be discerned. The type of $X$. simus, the anterior part of a right dentary, preserved the first tooth and part of the alveolus of the second. Both species were similar morphologically, except that the first tooth of $X$. simus was cylindrical (this appears to contradict the description of this tooth in $X$. rostratus as cylindrical in his 1887 description); the diastema, however, was about as long as the diameter of this tooth, as in the first species.

The type specimens of these two species are lost and were never figured, although that of $X$. rostratus (but not $X$. simus) appears in Scott's album (Vizcaíno et al., 2017: see above, Commentary on Ameghino's 1887 Taxa). The anterior portion of the skull illustrated in Scott's album is MACNA 6417 and is listed in MACN records as the type of $X$. simus. Associated with this skull portion is the nearly complete horizontal ramus of a left dentary, MACN-A 6418, and an unnumbered right astragalus. These remains clearly do not constitute the original type, as the horizontal ramus of the dentary (including cf1, $\mathrm{mf} 3$, and the alveoli of mf1 and $\mathrm{mf2}$ ) is almost entirely preserved. Further, they were collected by C. Ameghino during 1892-1893. Confusingly, MACN records identify a second specimen as the type of $X$. simus. This is MACN-A 4636, the anterior end of a left dentary preserving the first lower tooth and the partial alveolus of the second. This specimen, although it has a diastema nearly equal in length to the diameter of the cylindrical first tooth, is not the original type either. The latter was a portion of a right dentary, rather than of a left, and MACN-A 4636 was collected by C. Ameghino during 1890-1891.

Ameghino (1891a) provided a generic description of $X$ yophorus and erected three more species, $X$. sulcatus, $X$. atlanticus, and $X$. andinus. Of the generic characteristics that are somewhat distinct from those typically ascribed to Hapalops are that the first upper and lower teeth are small and worn approximately horizontally and the symphyseal spout is short and strongly tapered ("puntiaguda"; Ameghino, 1891a, p. 320). Ameghino (op. cit.) characterized $X$. sulcatus as twice as large as $X$. simus. Mf2 to Mf4 were described as rectangular, with the vestibular surface of Mf1 and Mf2 bearing a marked apicobasal sulcus on their vestibular surface, but with the vestibular and lingual margins of Mf3 and Mf4 being rounded. In the dentary, mf1 and mf2 were rectangular, bearing a pronounced apicobasal sulcus on the lingual surface, and mf3 was cylindrical.

Scott's album illustrates a right maxilla as $X$. sulcatus (Vizcaíno et al., 2017: Suppl. files, Appendix 1, p. 9, fig. 14b). This specimen is MACN-A 4629, clearly of a young individual given the open sutures, and identified by MACN records as the type of the species. The description and measurements given by Ameghino (1891a) for $X$. sulcatus leave no doubt that MACN-A 4629 is the maxillar portion on which this species is based. Similarly, MACN-A 4633, a nearly complete horizontal ramus of a left dentary preserving cf1-mf3, is almost surely the dentary discussed by Ameghino (1891a). A third specimen, MACN-A 4632, a portion of a right dentary, preserving $\mathrm{mf1}-\mathrm{mf} 3$, is assigned by MACN records to $X$. sulcatus. The dentition is similar morphologically and nearly identical in size to that of MACN-A 4633 , but in addition to the apicobasal sulcus on the lingual surface of $\mathrm{mf} 1$ and $\mathrm{mf} 2$, as in the latter specimen, the vestibular surface of $\mathrm{mf} 1$ and $\mathrm{mf} 2$ of MACN-A 4632 also bears an apicobasal sulcus. MACN-A 4629, 4632, and 4633 were recovered from Monte Observación by C. Ameghino during 1890-1891.

Xyophorus atlanticus is represented by several specimens in MACN. The type is MACN-A 4631, a mandible preserving nearly all of the left dentary (missing the tip of the coronoid 
and angular processes), including cf1-mf3, and the anterior part of the right dentary, preserving of 1 and the alveolus of mf1. It was collected by C. Ameghino from CorriguenKaik during 1890-1891. Ameghino (1891a) pointed out its salient features, among which are that it is larger and more robust than $X$. sulcatus, cf 1 is small and followed by a long diastema, and, most notably, mf1 and, in particular, mf2 are strongly rectangular, and mesiodistally compressed. Also noteworthy is that cf 1 is nearly triangular rather than cylindrical. This specimen appears in Scott's album (Vizcaíno et al., 2017: Suppl. files, Appendix 1, p. 9, fig. 14c) and is indicated as the type, but its condition at that time differed from its current condition. For example, matrix was present between the dentaries, the right mf2 was within its alveolus, and more of the right dentary was preserved. Despite these differences, there is no doubt that MACN-A 4631 is the same specimen as in fig. 14c of Scott's album. A second specimen assigned to $X$. atlanticus, MACN-A 4630, was recovered from Sehuen, Province of Santa Cruz, by C. Ameghino during 1890-1891. It is not particularly well preserved, but the form of the molariform teeth strongly resembles that of MACN-A 4631. A third specimen, MACN-A6435, collected by C. Ameghino during 1891-1892 from Corriguen-Kaik, is also assigned in MACN records to $X$. atlanticus. It preserves the better part of both dentaries, including left cf1-mf3 and right cf1-mf2. The mf1 and mf2, however, are not as strongly rectangular and compressed as in the other specimens assigned to $X$. atlanticus.

$X$ yophorus andinus was described as being of similar size to but somewhat more robust than $X$. atlanticus. Judging by Ameghino's (1891a) description, the specimen on which this species is based preserved the four lower teeth. The specimen was not illustrated, but MACN-A 4634, preserving the left cf1-mf3 and right cf1 and most of mf1 is identified as the type of this species. It was recovered by $\mathrm{C}$. Ameghino during 1890-1891 from Sehuen. The of1 is triangular, as in the type of $X$. atlanticus; $\mathrm{mf} 1$ and $\mathrm{mf} 2$ are mesiodistally compressed, but they are not rectangular, particularly mf1, which is elliptical. In this regard the molariform teeth resemble those of the type of H. ellipticus, MLP 4-44.

Ameghino (1894) erected $X$. crassissimus, based on MACN-A 6436, recovered by C. Ameghino from CorriguenKaik during 1892-1893. This author noted that the speci- men represented a species larger than $X$. andinus and possessed a short, high, and thick mandible. The specimen preserves the right $\mathrm{cf} 1$, left $\mathrm{mf3}$, mesial half of $\mathrm{mf2}$, and complete alveoli of the remaining teeth, except for the right mf3, for which only the mesial half of the alveolus is preserved. The mf1 and $\mathrm{mf} 2$ are mesiodistally compressed, but seem rather more elliptical than rectangular, although this is unclear owing to deformation.

The taxonomic confusion created by Mercerat (1891), who, as noted earlier, erected several genera and species without, in most cases, providing any diagnostic characters, extends to Xyophorus. Several species that Mercerat (1891) erected for Eurysodon, such as E. nasutus, E. boulei, and E. rostratus, were considered by Ameghino (1891c) as likely synonyms of $X$. rostratus, $X$. sulcatus, and $X$. altanticus, respectively. Ameghino (1894) formally synonymized $E$. boulei with $X$. sulcatus.

Scott (1903) included Xyophorus as a synonym of Hapalops. Specifically, Scott (op. cit., p. 217) considered both Ameghino's (1891a) X. sulcatus and Mercerat's (1891) Eurysodon nasutus as synonyms of Hapalops elongatus. Scott (1904, p. 239) transferred $X$. rostratus to Hapalops, as $H$. rostratus, and synonymized, with reservation, $X$. simus with it. Scott (1904: pl. 43, fig.1, 1a) considered the type of $X$. rostratus (noted above as now lost and never illustrated) as an unsatisfactory fragment of a very young animal (explaining its small size) and instead based his description on YPMVPPU 15342, illustrated by him in the cited figure. This author reasoned that the type of $X$. simus represented an older and therefore larger individual of the same species. Scott (1904, p. 241; 260, respectively) transferred $X$. atlanticus to $H$. atlanticus and synonymized $X$. andinus with it, and transferred $X$. crassissimus to Hapalops as $H$. crassissimus. Scott (1904, p. 260) transferred Mercerat's Eurysodon boulei to Hapalops and included $X$. sulcatus in its synonymy list, as " $X$. sulcatus Amegh., in part; Enum. Synopt. Des Mamm. Foss. de Patagonie; 1894, p. 155." This likely refers to Ameghino's (1891c; 1894) synonymy of E. boulei with X. sulcatus. Many of Scott's $(1903,1904)$ actions were not accompanied by justification. In the case of $H$. crassissimus and $H$. boulei, Scott (1904, p. 258) listed them as among the species "concerning which I could arrive at no definite conclusions." Adding to the confusion, Scott (1904) transferred Mercerat's 
(1891) Eurysodon rostratus to Hapalops as $H$. rostratus, not to be confused with $H$. rostratus (Ameghino, 1887); that is, $X$. rostratus, which (as noted above) was transferred by Scott (1904) to Hapalops.

Clearly, the taxonomic and systematic issues with many of the above mentioned taxa require careful and rigorous analyses, but such efforts are impeded by the confusion over which specimens Ameghino, Mercerat, and Scott used in their decisions, compounded by the fact that the original types of several taxa are no longer available. In the case of Xyophorus, the type specimen of the type species, $X$. rostratus, is lost and was never illustrated, as is the case as well for the second-named species, $X$. simus, which Scott (1904) considered as a synonym of $X$. rostratus. Given that $X$. rostratus is a valid name, one might accept Scott's (1904) decision as first reviewer to recognize YPM-VPPU 15342, designate it the neotype of $X$. rostratus, and base the concept of the species on this specimen. Alternatively, should the concept of $X$. rostratus not be reconcilable with these specimens, then the Commission may be petitioned to suppress the name and designate $X$. simus as the type species of the genus, perhaps with MACN-A 4617 and MACN-A 4618, the remains that Ameghino came to regard as the type of his species $X$. simus, as neotypes. In MACN-A $4618 \mathrm{mf1}$ and $\mathrm{mf} 2$ are not preserved but their alveoli suggest the typical (i.e., mesiodistally uncompressed) form present in Hapalops. In any event, while it might be allowed that YPM-VPPU 15342 and MACN-A 4618 do represent Hapalops, it is not clear that $X$. atlanticus, $X$. andinus, and $X$. crassissimus do, given the striking mesiodistal compression of $\mathrm{mf} 1$ and $\mathrm{mf} 2$ in the type specimens of these species.

Despite Scott's $(1903,1904)$ synonymy of Xyophorus with Hapalops, subsequent workers have largely maintained Xyophorus (but see Perea, 1999), as manifest in the erection of X. bondesioi Scillato-Yané, 1979 and X. villarroeli SaintAndré, 1996, and their recognition by, for example, Pujos et al. (2007) and Croft et al. (2009). The position of Xyophorus among other sloths has varied, as noted by Brandoni (2014). Croft et al. (2009) recognized $X$. cf. bondesioias a nothrotheriid, whereas Xyophorus was considered as a basal megatherioid by De luliis et al. (2011), and as a megatherioid of uncertain position by Pujos et al. (2011). Brandoni (2014; see also Brandoni et al., 2017) attempted to clarify the position of
Xyophorus by recognizing two groups within Xyophorus. One included the classically known species with affinities to basal megatherioids from the Early-Middle Miocene SCF of Argentine Patagonia, for which this author retained Xyophorus. The second group, including species recorded from the Middle-Late Miocene of Argentina and Bolivia, were designated as 'Xyophorus' and considered as nothrotheriids. In other words, Xyophorus was retained for Ameghino's (1887, 1891a, 1894) species, whereas those erected by Scillato-Yané (1979) and Saint-André (1996) were designated 'Xyophorus,' ' $X$.' bondesioi and 'X.' villarroelli, respectively. Brandoni et al. $(2017$, p. 6) explained that erection of a new genus for 'Xyophorus'could be justified on several features, but that "the scarcity of materials and their poor state of preservation prevents us from making a nearly complete diagnosis for a new genus".

Among the distinguishing features identified by Brandoni (2014) and Brandoni et al. (2017) are that the molariforms, at least mf1 and mf2, are nearly rectangular and mesiodistally compressed and apicobasal sulci are present on the lingual and vestibular surface of at least the mf1 and mf2 of 'Xypohorus' but absent in Xyophorus. However, Brandoni (2014) and Brandoni et al. (2017) considered only $X$. atlanticus, $X$. simus, and $X$. crassissimus. The first two Xyophorus species erected by Ameghino (1887) were not considered, which is justified given that the original types are lost and were never figured, and the MACN specimens recorded as the types are clearly not so. However, the features present in Ameghino's (1891a) X. sulcatus, for which the type is available (see above), do not agree with some of the distinguishing characters outlined by Brandoni (2014) and Brandoni et al. (2017). Ameghino (1891a) noted the presence of an apicobasal sulcus on the lingual surface of mf1 and mf2, clearly visible on MACN-A 4633. Interestingly, an apicobasal sulcus is present on the lingual and vestibular surfaces of mf1 and mf2 in MACN-A 4632. Thus, the presence of such sulci in the molariforms of at least some basal Santacrucian megatherioids predates their appearance in the Middle to Late Miocene 'Xyophorus' species. Also, the teeth of $X$. sulcatus are not mesiodistally compressed.

It is not clear how consideration of such features reflect the relationships and status of the Santacrucian megatherioids. Xyophorus atlanticus, $X$. andinus, and $X$. crassissimus 
seem to form a group, based on the marked mesiodistal compression of at least $\mathrm{mf} 1$ and $\mathrm{mf} 2$ and absence of apicobasal sulci. The dentition of $X$. sulcatus sets it apart from this group of species. In $X$. sulcatus $\mathrm{mf} 1$ and $\mathrm{mf} 2$ are uncompressed, resembling the condition present in remains that have typically been assigned to Hapalops, but these teeth bear apicobasal sulci on at least their lingual surface and possibly also on their vestibular surface if MACN-A 4632 is correctly assigned to $X$. sulcatus. Regardless, the evidence suggests that lingual and vestibular apicobasal sulci on mf1 and mf2 arose among Santacrucian megatherioid sloths.

\section{Trematherium}

Ameghino (1887, p. 22) described Trematherium intermixtum as possessing a small and cylindrical cf1, followed by "eliptico-cilíndricas"mf1-mf3, as in Hapalops. The distinguishing feature emphasized by this author was the extremely small posterolateral opening of the mandibular canal. It is unclear how Ameghino (1887) was able to note the presence and condition of $\mathrm{cf} 1$, given that this tooth is not preserved in the type. This may be a situation similar to that noted above for Hapalops rectangularis; that is, Ameghino considered Trematherium to be morphologically very similar to Hapalops (and thus deduced the form and size of an unpreserved cf1), but differing in possessing an extremely small opening of the mandibular canal. This is a reasonable assumption, for had a Hapalops-like morphology been preserved, it is likely that Ameghino (1887) would have reported the length of the diastema. Another possibility is that a more anterior portion was present but has since become lost. This suggestion seems less likely, based on Ameghino's (1889) contradictory description, which noted the presence of only the base of the cf1 alveolus that indicated little separation between cf1 and mf1, but that only the distal part of the mf1 alveolus was preserved, and the image in Scott's album (Vizcaíno et al., 2017), which presents the condition of this specimen as it currently remains.

The type specimen of $T$. intermixtum is MLP 4-45 (Fig. 2.9-10). A second specimen is indicated in MACN records for this species, MACN-A 2097, a right mandibular ramus lacking teeth that also appears in Scott's album (Vizcaíno et al. 2017: Suppl. files, Appendix 1, p. 30, fig. 62.2). This specimen preserves most of the of 1 alveolus, which is separated by a narrow gap from the mf1 alveolus, but this specimen was recovered by C. Ameghino in 1889-1890 and could not have been available for, at least, Ameghino's (1887) publication. Further, the alveoli of mf1 and mf2 are transversely compressed and slightly oval compared to those of the type MLP 4-45, suggesting that the specimens are unlikely conspecific. On the other hand, the homologous elements of MLP 4-45 and MLP 4-33, the type of Hapalops indifferens, are nearly identical in size and form, suggesting that they are conspecific. Ameghino (1889) named a second species, T. nanum, drawing attention to its smaller size and, particularly, very small openings for the posterolateral opening of the mandibular canal. Mones (1986) indicated this specimen as lost, but MACN records indicate that MACN-A 4617 is the type of this species. It differs from MACN-A 2097 at least in possessing a diastema, but the two portions of the left mandibular ramus of this specimen do not belong to the same individual.

\section{CONCLUDING THOUGHTS}

The recovery of new remains from localities along the Río Santa Cruz provides an opportunity to revisit the taxa established by Ameghino (1887) on fossils recovered by his brother Carlos from localities along this river. These latter remains are the types of numerous Santacrucian mammalian taxa erected by Ameghino (1887), although several are lost. The new specimens reported here, along with other recently recovered collections from the SCF, are potentially useful in verifying Ameghino's original descriptions and revision of the Santacrucian taxa. With particular regard to Santacrucian sloths, these fossils provide a window for reconsideration of Scott's $(1903,1904)$ taxonomic and systematic decisions, which have been largely and uncritically accepted for more than a century. Although the latter author's efforts were monumental in scope, they require analyses by modern methods.

\section{ACKNOWLEDGEMENTS}

We thank the collection managers of the Vertebrate Paleontology collections at MLP (M. Reguero), MACN (L. Chornogubsky), and NHMUK (P. Brewer), J. Flynn and J. Galkin (AMNH), W.F. Simpson and K. Angielczyk (FMNH), W. Joyce and D. Brinkman (YPM), and 
the Dirección de Patrimonio, Secretaría de Cultura de Estado (Province of Santa Cruz), and Museo Regional Provincial P.M.J. Molina. We thank especially L. Acosta, L. Chornogubsky, J. Cuitiño, L. Gonzalez, V. Krapovickas, S. Hernández del Pino, N.A. Muñoz, A. Racco, and J. Spradley for their collaboration during field work. We thank the comments and suggestions of the two reviewers and the editor for their efforts in helping improve the quality of this paper, and $\mathrm{A}$. Mones for extended discussions on nomenclatural issues. This is a contribution to the projects PIP-CONICET 00781 (to J.C. Fernicola), UNLP 11/N867, PICT 2013-0389 (to S.F. Vizcaíno) and PICT 2017-1081 (to M.S. Bargo), National Science Foundation grants 0851272,1348259 , and National Geographic Society 9167-12 (to R.F. Kay).

\section{REFERENCES}

Ameghino, F. 1887. Enumeración sistemática de las especies de mamíferos fósiles coleccionados por Carlos Ameghino en los terrenos eocenos de Patagonia Austral y depositados en el Museo de La Plata. Boletín del Museo de La Plata, p. 1-26.

Ameghino, F. 1889. Contribución al conocimiento de los mamíferos fósiles de la República Argentina. Actas de la Academia Nacional de Ciencias en Córdoba 6: 1-1027 + Atlas: [xi], 98 pls. Buenos Aires.

Ameghino, F. 1891a. Nuevos restos de mamíferos fósiles descubiertos por Cárlos Ameghino en el Eoceno inferior de la Patagonia austral. Especies nuevas, adiciones y correcciones. Revista Argentina de Historia Natural 1: 289-328.

Ameghino, F. 1891b. Caracteres diagnósticos de cincuenta especies nuevas de mamíferos fósiles argentinos. Revista Argentina de Historia Natural 1: 129-167.

Ameghino, F. 1891c. Observaciones críticas sobre los mamíferos eocenos de la Patagonia austral. Revista Argentina de Historia Natural 1: 328-380.

Ameghino, F. 1894. Énumération synoptique des espèces de mammifères fossiles des formations éocènes de Patagonie. Boletín de la Academia Nacional de Ciencias en Córdoba 13: 259-455.

Ameghino, F. 1897. Mammifères crétacés de l'Argentine. Deuxième contribution à la connaissance de la faune mammalogique des couches à Pyrotherium. Boletín del Instituto Geográfico Argentino18: 406-429; 431-521.

Ameghino, F. 1898. Sinopsis geológica-paleontológica de la Argentina. In: De La Fuente (Ed.), Segundo Censo de la República Argentina Tomo I (Territorio). Taller Tipográfico de la Penitenciaría Nacional, Buenos Aires, p. 111-255.

Amson, E., Muizon, C., and Gaudin, T.J. 2016. A reappraisal of the phylogeny of the Megatheria (Mammalia: Tardigrada), with an emphasis on the relationships of the Thalassocninae, the marine sloths. Zoological Journal of the Linnean Society 179: 217-236.

Amson, E., de Muizon, C., Laurin, M., Argot, C., and de Buffrénil, V. 2014. Gradual adaptation of bone structure to aquatic lifestyle in extinct sloths from Peru. Proceedings of the Royal Society $B$ Biological Sciences 281: 1-6.

Asher, R.J., and Helgen, K.M. 2010. Nomenclature and placental mammal phylogeny. BMC Evolutionary Biology 10: 1-9.

Bargo, M.S. 2001. The ground sloth Megatherium americanum: skull shape, bite forces, and diet. Acta Paleontologica Polonica, Special Issue 46: 41-60.

Bargo, M.S., and Vizcaíno, S.F. 2008. Paleobiology of Pleistocene ground sloths (Xenarthra, Tardigrada): biomechanics, morphogeometry and ecomorphology applied to the masticatory apparatus. Ameghiniana 45: 175-196.
Bargo, M.S., Toledo N., and Vizcaíno, S.F. 2012. Paleobiology of the Santacrucian sloths and anteaters (Xenarthra, Pilosa). In: S.F. Vizcaíno, R.F. Kay, and M.S. Bargo (Eds.), Early Miocene Paleobiology in Patagonia: high-latitude paleocommunities of the Santa Cruz Formation. Cambridge University Press, Cambridge, p. 216-242.

Bargo, M.S., Vizcaíno, S.F., and Kay, R.F. 2009. Predominance of orthal masticatory movements in the early Miocene Eucholaeops (Mammalia, Xenarthra, Tardigrada, Megalonychidae) and other megatherioid sloths. Journal of Vertebrate Paleontology 29: 870-880.

Bordas, A.F. 1939. Los restos de mamíferos de la serie continental postpatagoniana de la Meseta del Castillo. Physis 14: 435-446.

Brandoni, D. 2014. "Xyophorus" sp. en el Mioceno Medio de Chubut: implicancias sistemáticas, biogeográficas y biocronológicas del registro de un Nothrotheriinae en el Neógeno de la Argentina. Ameghiniana 51: 94-105.

Brandoni, D., González Ruiz, L., Reato, A., and Martin, G. 2017. Chronological implications of the nothrotheriid 'Xyophorus' (Mammalia, Xenarthra) from the Collón Curá Formation (Miocene of Patagonia, Argentina). Historical Biology doi: 10.1080/08912963.2017.1398748

Carlini, A.A., Brandoni, D., and Dal Molin, C.N. 2013. A new genus and species of Planopinae (Xenarthra: Tardigrada) from the Miocene of Santa Cruz Province, Argentina. Zootaxa 3694: 565-578.

Croft, D.A., Anaya, F., Auerbach, D., Garzione, C., and MacFadden, B.J. 2009. New data on Miocene Neotropical provinciality from Cerdas, Bolivia. Journal of Mammalian Evolution 16: 175-198.

Cuitiño, J.I., Fernicola, J.C., Kohn, M., Trayler, R., Naipauer, M., Bargo, M.S., Kay, R.F., and Vizcaíno, S.F. 2016. U-Pb geochronology of the Santa Cruz Formation (early Miocene) at the Río Bote and Río Santa Cruz (southernmost Patagonia, Argentina): implications for the correlation of fossil vertebrate localities. Journal of South America Earth Sciences 70: 198-210.

Cuitiño, J.I., Fernicola, J.C., Raigemborn, M.S., and Krapovickas, V. 2019a. Stratigraphy and depositional environments of the Santa Cruz Formation (Early-Middle Miocene) along the Río Santa Cruz, Southern Patagonia, Argentina. In: J.C. Fernicola, M.S. Bargo, S.F. Vizcaíno, and R.F. Kay (Eds.), Early-Middle Miocene Paleontology in the Río Santa Cruz, Southern Patagonia, Argentina. 130 years since Ameghino, 1887. Publicación Electrónica de la Asociación Paleontológica Argentina 19: 14-33.

Cuitiño, J.I., Vizcaíno, S.F., Bargo, M.S., and Aramendía, I. $2019 \mathrm{~b}$. Sedimentology and fossil vertebrates of the Santa Cruz Formation (early Miocene) in Lago Posadas, a sub-Andean locality of southwestern Patagonia. Andean Geology 46: 383-420.

De luliis, G. 1994. Relationships of the Megatheriinae, Nothrotheriinae, and Planopsinae: some skeletal characteristics and their importance for phylogeny. Journal of Vertebrate Paleontology 14: 577-591.

De luliis, G., Gaudin, T.J., and Vicars, M. 2011. A new genus and species of nothrotheriid sloth (Xenarthra, Tardigrada, Nothrotheriidae) from the late Miocene (Huayquerian) of Peru. Palaeontology 54: 171-205.

De luliis, G., Pujos, F., Toledo, N., Bargo, M.S., and Vizcaíno, S.F. 2014. Eucholoeops Ameghino, 1887 (Xenarthra, Pilosa, Megalonychidae) from the Santa Cruz Formation, Argentine Patagonia: implications for revising the systematics of Santacrucian sloths. Geodiversitas 36: 209-255.

Delsuc, F., Martínez, J.G., Poinar. H.N., Kuch, M., Mead, J.I., Gibb, G.C., McDonald, H.G., Karpinski, E., Hackenberger, D., MacPhee, R.D.E., Szpak, P., Billet, G., and Hautier, L. 2019. Ancient mitogenomes reveal the evolutionary history and biogeography of sloths. Current Biology doi: 10.1016/j.cub.2019.05.043 
Dubois, A. 2010. Retroactive changes should be introduced in the Code only with great care: problems related to the spellings of nomina. Zootaxa 2426: 1-42

Fernicola, J.C. 2011. Implicancias del conflicto Ameghino-Moreno sobre la colección de mamíferos fósiles realizada por Carlos Ameghino en su primera exploración al río Santa Cruz, Argentina. Revista del Museo Argentino de Ciencias Naturales, nueva serie 13: 41-57.

Fernicola, J.C., Cuitiño, J., Vizcaíno, S.F., Bargo, M.S., and Kay, R.F. 2014. Fossil localities of the Santa Cruz Formation (early Miocene, Patagonia, Argentina) prospected by Carlos Ameghino in 1887 revisited and the location of the Notohippidian. Journal of South America Earth Sciences 52: 9-107.

Fernicola, J.C., Bargo, M.S., Vizcaíno, S.F., and Kay, R.F. 2019. Historical background for a revision of the paleontology of the Santa Cruz Formation (Early-Middle Miocene) along the Río Santa Cruz, Patagonia, Argentina. In: J.C. Fernicola, M.S. Bargo, S.F. Vizcaíno, and R.F. Kay (Eds.), Early-Middle Miocene Paleontology in the Río Santa Cruz, Southern Patagonia, Argentina. 130 years since Ameghino, 1887. Publicación Electrónica de la Asociación Paleontológica Argentina 19: 1-13.

Fleagle, J.H., Perkins, M. E., Heizler, M.T., Nash, B., Bown, T.M., Tauber, A.A., Dozo, M.T., and Tejedor M.F. 2012. Absolute and relative ages of fossil localities in the Santa Cruz and Pinturas Formations. In: S.F. Vizcaíno, R.F. Kay, and M.S. Bargo (Eds), Early Miocene Paleobiology in Patagonia: high-latitude paleocommunities of the Santa Cruz Formation. Cambridge University Press, Cambridge, p. 41-58.

Gaudin, T.J. 2004. Phylogenetic relationships among sloths (Mammalia, Xenarthra, tardigrada): the craniodental evidence. Zoological Journal of the Linnean Society, London 140: 255-305.

Hautier, L., Gomes Rodrigues, H., Billet, G., and Asher, R.J. 2016.The hidden teeth of sloths: evolutionary vestiges and the development of a simplified dentition. Scientific Reports 6: 27763.

Hoffstetter, R. 1961. Description d'un squelette de Planops (Gravigrade du Miocène de Patagonie). Mammalia 25: 57-96.

Hoffstetter, R. 1982. Les Edentés Xénarthres, un groupe singulier de la faune néotropicale (origine, affinités, radiation adaptative, migrations et extinctions). In: E. Montanaro Gallitelli (Ed.), Palaeontology, Essential of Historical Geology. Proccedings First International Meeting of Paleontology. S.T.E.M. Mucchi, Modena, p. 385-443.

International Commission on Zoological Nomenclature, 1999. International Code of Zoological Nomenclature. Fourth ed., online version at: http://www.iczn.org/iczn/index.jsp.

Kay, R.F., Vizcaíno, S.F., and Bargo, M.S. 2012. A review of the paleoenvironment and paleoecology of the Miocene Santa Cruz Formation. In: S.F. Vizcaíno, R.F. Kay, and M.S. Bargo (Eds.), Early Miocene Paleobiology in Patagonia: High-Latitude Paleocommunities of the Santa Cruz Formation. Cambridge University Press, Cambridge, p. 331-365.

Lydekker, R. 1894. Contributions to the knowledge of the fossil vertebrates of Argentina.The extinct edentates of Argentina/Contribuciones al conocimiento de los vertebrados fósiles de la Argentina. Los edentados extinctos de la Argentina. Part II. Anales del Museo de La Plata, Paleontología Argentina 1: 1-118.

Marshall, L.G. 1975. The Handel T. Martin paleontological expedition to Patagonia in 1903. Ameghiniana 12: 109-111.

Marshall, L.G. 1976. Fossil localities for Santacrucian (Early Miocene) mammals, Santa Cruz Province, Southern Patagonia, Argentina. Journal of Paleontology 50: 1129-1142.
McDonald, H.G., and De luliis, G. 2008. Fossil history of sloths. In: S.F. Vizcaíno and W.J. Loughry (Eds), The Biology of the Xenarthra. The University of Florida Press, Gainesville, p. 39-55.

McKenna, M.C., and Bell, S.K. 1997. Classification of Mammals above the Species Level. Columbia University Press, New York, p. 631.

Matheos, S.D., and Raigemborn, M.S. 2012. Sedimentology and paleoenvironment of the Santa Cruz Formation. In: S.F. Vizcaíno, R.F. Kay, and M.S. Bargo (Eds.), Early Miocene Paleobiology in Patagonia: High-Latitude Paleocommunities of the Santa Cruz Formation. Cambridge University Press, Cambridge, p. 59-82.

Mercerat, A. 1891. Datos sobre restos de mamíferos fósiles pertenecientes a los Bruta conservados en el Museo de La Plata y procedentes de los terrenos eocenos de Patagonia. Revista del Museo de La Plata 2: 5-46.

Meredith, R.W., Janečka, J.E., Gatesy, J., Ryder, O.A., Fisher, C.A., Teeling, E.C., Goodbla, A., Eizirik, E., Simão, T.L.L., Stadler, T., Rabosky, D.L., Honeycutt, R.L., Flynn, J.J., Ingram, C.M., Steiner, C., Williams, T.L., Robinson, T.J., Burk-Herrik, A., Westerman, M., Ayoub, N.A., Springer, M.S., and Murphy, W.J. 2011. Impacts of the Cretaceous Terrestrial Revolution and KPg extinction on mammal diversification. Science 334: 521-524.

Mones, A. 1986. Palaeovertebrata Sudamericana. Catálogo Sistemático de los Vertebrados fósiles de América del Sur. Parte I. Lista Preliminar y Bibliografía. Courier Forschungsinstitut Senckenberg 82: 1-625.

Mones, A. 1989. Nomen dubium vs. Nomen vanum. Journal of Vertebrate Palentology 9: 232-234.

Moreno, F.P. 1879. Viaje a la Patagonia Austral, emprendido bajo los auspicios del Gobierno Nacional, 1876-1877. Imprenta de La Nación, Buenos Aires, 460 p.

O'Leary, M.A., Giallombardo, A., Luo, Zhe-Xi, Meng, J., Bloch, J.I., Giannini, N.P., Ni, X., Flynn, J.J., Gaudin, T.J., Goldberg, S.L., Novacek, M.J., Kraatz, B.P., Perini, F.A., Randall, Z.S., Simmons, N.B., Rougier, G.W., Spaulding, M., Sargis, E.J., Velazco, P.M., Silcox, M.T., Weksler, M., Wible, J.R., and Cirranello, A.L. 2013. The placental mammal ancestor and the post-K-Pg radiation of placentals. Science 662: 339.

Parras, A., Dix, G.R., and Griffin, M. 2012. Sr-isotope chronostratigraphy of Paleogene/Neogene marine deposits: Austral Basin, southern Patagonia (Argentina). Journal of South American Earth Sciences 37: 122-135.

Pascual, R. 1961. Una nueva superfamilia 'Entelopsoidea' descripción de la nueva especie 'Entelops parodii'. Acta Geológica Lilloana 3: 127-146

Pascual, R., Ortega Hinojosa, E.J., Gondar, D., and Tonni, E.P. 1965. Las Edades del Cenozoico mamalífero de la Argentina, con especial atención a aquellas del territorio bonaerense. Anales de la Comisión de Investigaciones Científicas de la Provincia de Buenos Aires 6: 165-193.

Perea, D. 1999. Un singular grupo de perezosos, los 'Nothrotheriinae' (Xenarthra). Boletín de la Sociedad Zoológica del Uruguay, 2 época 10: 1-8.

Perkins, M.E., Fleagle, J.G., Heizler, M.T., Nash, B, Bown, T.M., Tauber, A.A., and Dozo, M.T. 2012. Tephrochronology of the Miocene Santa Cruz and Pinturas Formations, Argentina. In: S.F. Vizcaíno, R.F. Kay, and M.S. Bargo (Eds.), Early Miocene Paleobiology in Patagonia: High-Latitude Paleocommunities of the Santa Cruz Formation. Cambridge University Press, Cambridge, p. 23-40.

Presslee, S., Slater, G.J., Pujos, F.R., Forasiepi, A.M., Fischer, R., Molloy, K., Mackie, M., Olsen, J.V., Kramarz, A., Taglioretti, M., Scaglia, F., Lezcano, M., Lanata, J.L., Southon, J., Feranec, R., Bloch, J., 
Hadjuk, A., Martin, F.M., Gismondi, R.S., Reguero, M., de Muizom, C., Greenwood, A., Chait, B.T., Penkman, K., Collins, M., and MacPhee, R.D. 2019. Palaeoproteomics resolves sloth relationships. Nature Ecology and Evolution doi: 10.1038/s41559-0190909-z

Pujos, F., and De luliis, G. 2007. Late Oligocene Megatherioidea fauna (Mammalia: Xenarthra) from Salla-Luribay (Bolivia): new data on basal sloth radiation and Cingulata-Tardigrada split. Journal of Vertebrate Paleontology 27: 132-144.

Pujos, F., De luliis, G., Argot, C., and Werdelin, L. 2007. A peculiar climbing Megalonychidae from the Pleistocene of Peru and its implication for sloth history. Zoological Journal of the Linnean Society 149: 179-235.

Pujos, F., De luliis, G., and Mamani Quispe, B. 2011. Hiskatherium saintandreigen. et sp. nov.: an unusual sloth from the Laventan of Quebrada Honda (Bolivia) and an overview of middle Miocene, small megatherioids. Journal of Vertebrate Paleontology 31: $1131-1149$.

Racco, A., Fernicola, J.C., Bargo, M.S., Vizcaíno, S.F., and De luliis, G. 2018. On the type of Schismotherium fractum Ameghino, 1887 (Xenarthra, Folivora, Megatherioidea) from the Early Miocene Santa Cruz Formation (Santa Cruz province, Argentina). Ameghiniana 55: 117-125.

Raigemborn, M.S., Matheos, S.D., Krapovickas, V., Vizcaíno, S.F., Bargo, M.S., Kay, R.F., Fernicola, J.C., and Zapata, L. 2015. Paleoenvironmental reconstruction of the coastal Monte Léon and Santa Cruz formations (early Miocene) at Rincón del Buque, southern Patagonia: A revisited locality. Journal of South American Earth Sciences 60: 31-55.

Saint-André, P.A. 1996. Deux nouveaux Édentés (Mammalia, Xenarthra) Trachycalyptoides achirense nov. gen. et nov. sp. (Glyptodontidae, Sclerocalyptinae) et Xyophorus villarroeli nov. sp. (Megatheriidae, Nothrotheriinae) du Huayquérien (Miocène supérieur) de l'Altiplano bolivien. Bulletin du Museum National d'Histoire Naturelle, $4^{\circ}$ Serie 18: 79-106.

Scillato-Yané, G.J. 1979. Nuevo Nothrotheriinae (Edentata, Tardigrada) de Edad Chasiquense (Plioceno temprano) del sur de la Prov. de Buenos Aires (Argentina). Su importancia bioestratigráfica, filogenética y paleobiogeográfica. $7^{\circ}$ Congreso Geológico Argentino (Neuquén), Actas 2: 449-457.

Scott, W.B. 1903. Mammalia of the Santa Cruz beds. Part I. Edentata. In: W.B. Scott (Ed.), Reports of the Princeton University Expeditions to Patagonia 1896-1899. Vol. 5, Paleontology 2, Princeton University Press, Princeton, p. 1-226.

Scott, W.B. 1904. Mammalia of the Santa Cruz beds. Part I. Edentata. In: W.B. Scott (Ed.), Reports of the Princeton University Expeditions to Patagonia 1896-1899. Vol. 5, Paleontology 2, Princeton University Press, Princeton, p. 227-364.

Simpson, G.G. 1941. A Miocene sloth from Southern Chile. American Museum Novitates 1156: 1-6.

Simpson, G.G. 1945. The principles of classification and a classification of mammals. Bulletin of the American Museum of Natural History 85: 1-350.
Simpson, G.G. 1948. The beginning of the age of mammals in South America, 1. Bulletin of the American Museum of Natural History 91: $1-232$.

Vizcaíno, S.F., Bargo M.S., and Fariña, R.A. 2008. Form, function and paleobiology in xenarthrans. In: S.F. Vizcaíno, and W.L. Loughry (Eds.), The Biology of the Xenarthra. University Press of Florida, Florida, p. 86-99.

Vizcaíno, S.F., Kay, R.F., and Bargo, M.S. 2012a. Early Miocene Paleobiology in Patagonia: high-latitude paleocommunities of the Santa Cruz Formation. Cambridge University Press, Cambridge, 370 pp.

Vizcaíno, S.F., Kay R.F., and Bargo M.S. 2012b. Background for a paleoecological study of the Santa Cruz Formation (late Early Miocene) on the Atlantic Coast of Patagonia. In: S.F. Vizcaíno, R.F. Kay, and M.S. Bargo (Eds.), Early Miocene Paleobiology in Patagonia: high-latitude paleocommunities of the Santa Cruz Formation.Cambridge University Press, Cambridge, p. 1-22.

Vizcaíno, S.F., and Bargo, M.S. 2013b. De Patagonia a Budapest: caminos europeos de fósiles santacrucenses (1845-1956). Museo 26: $36-42$

Vizcaíno, S.F., Bargo M.S., and Fernicola, J.C. 2013a. Expediciones paleontológicas durante los siglos XIX y XX a la Formación Santa Cruz (Mioceno Inferior, Patagonia) y destino de los fósiles. $3^{\circ}$ Congreso Argentino de Historia de la Geología (Salta), Actas: 231-246.

Vizcaíno, S.F., Brinkman, P.D., and Kay, R.F. 2016. On the objectives and results of the Handel T. Martin paleontological expedition (1903-04) to the Santa Cruz Formation in southern Patagonia. Revista del Museo de La Plata 1: 316-333.

Vizcaíno, S.F., De luliis, G., Brinkman, P.D., Kay, R.F., and Brinkman, D.L. 2017. On an album of photographs recording fossils in the "Old Collections" of the Museo de La Plata and Ameghino's private collection at the beginning of the XX' ${ }^{\text {th }}$ Century. Publicación Electrónica de la Asociación Paleontológica Argentina 17: 14-23.

Vizcaíno, S.F., Bargo, M.S., Cuitiño, J.I., Pérez, M.E., Muñoz, N.A., Aramendía, I., Tomassini, R.L., and Kay, R.F. 2018. The outstanding Río Chalía (= Sehuen) outcrops of the Santa Cruz Formation (Early Miocene, Burdigalian) and its fossil vertebrate content. Publicación Electrónica de la Asociación Paleontológica Argentina 19, Suplemento de resúmenes, p. R85.

Doi: 10.5710/PEAPA.06.08.2019.297

Recibido: 6 de mayo 2019

Aceptado: 6 de agosto 2019 


\section{APPENDIX 1 - List of new sloths remains recovered from the Santa Cruz Formation along the Río Santa Cruz}

Barrancas Blancas (Estancias Aguada Grande and Santa Lucía)

\begin{tabular}{|c|c|c|}
\hline$M P M-P V$ & Taxa & Description \\
\hline 19303 & Mylodontidae indet. & Ungual phalanx and right astragalus \\
\hline 19304 & Megatherioidea indet. & Ungual phalanx \\
\hline 19305 & Megatherioidea indet. & Several tooth, mandibular, and palatal fragments, ungual phalanx, and several unidentifiable fragments \\
\hline 19306 & Megatherioidea indet. & Left astragalus \\
\hline 19307 & Megatherioidea indet. & $\begin{array}{l}\text { Small anterior portion of right dentary, preserving cf1, posterior part of spout and partial region of diastema. } \\
\text { Isolated teeth fragment, proximal humerus }\end{array}$ \\
\hline 19308 & Megatherioidea indet. & Two tooth fragments \\
\hline 19309 & Megatherioidea indet. & Ungual phalanx \\
\hline 19310 & Megatherioidea indet. & Right astragalus \\
\hline 19311 & Megatherioidea indet. & Right astragalus \\
\hline 19312 & Megatherioidea indet. & Tooth fragments \\
\hline 19313 & Megatherioidea indet. & Ungual phalanx \\
\hline 19314 & Megatherioidea indet. & Metatarsal IV \\
\hline 19315 & Megatherioidea indet. & Metatarsal III \\
\hline 19316 & cf. Hapalops & Distal and proximal humerus, left astragalus, ungual phalanx, and several fragments \\
\hline 19317 & Hapalops $c f$. elongatus & $\begin{array}{l}\text { Portion of right dentary preserving distal part of cf } 1 \text { alveolus, } m f 1 \text { and } m f 2 \text { completely, and all but distolingual } \\
\text { portion of mf3 }\end{array}$ \\
\hline 19318 & Hapalops $c f$. elongatus & $\begin{array}{l}\text { Anterior portion of skull, preserving left Cf1, Mf1-Mf3, Mf4 broken, and right Mf1-Mf3 (Mf2 broken vestibularly, } \\
\text { and Mf3 broken, lacking its occlusal surface) }\end{array}$ \\
\hline 19319 & Megatherioidea indet. & Ungual phalanges \\
\hline 19320 & Megatherioidea indet. & Ungual phalanx \\
\hline 19321 & Megatherioidea indet. & Tooth fragments and fragmented skull \\
\hline 19322 & Megatherioidea indet. & Mandibular fragment: portion of the spout with cf 1 broken \\
\hline
\end{tabular}

Segundas Barrancas Blancas (Estancias Cordón Alto and El Tordillo)

\begin{tabular}{|c|c|c|}
\hline 19323 & Planopinae indet. & Right astragalus \\
\hline 19324 & Hapalops sp. & Astragalus, ungual phalanx and several fragments \\
\hline 19325 & Megatheriidae indet. & Tooth fragments of a large-sized sloth \\
\hline 19326 & $\begin{array}{l}\text { Nematherium } \\
\text { longirostris }\end{array}$ & Left mandibular fragment with mf1 alveolus, isolated teeth, and several skull fragments \\
\hline 19327 & Megatherioidea indet. & Ungual phalanx \\
\hline 19328 & $\begin{array}{l}\text { Schismotherium } c f \text {. } \\
\text { fractum }\end{array}$ & Portion of left dentary with mf1-2 alveoli, alveoli of cf1 and mf3 incomplete, and ungual phalanx \\
\hline 19329 & Megatherioidea indet. & Mandibular fragment with two broken teeth \\
\hline 19330 & Megatherioidea indet. & Teeth and ungual phalanx \\
\hline 19331 & Megatherioidea indet. & Postcranial fragments, probably of the same individual; one tooth \\
\hline 19332 & Hapalops sp. & Right astragalus \\
\hline 19333 & Megatheriidae indet. & Broken teeth of a large-sized sloth \\
\hline 19334 & Megatherioidea indet. & Distal tibia \\
\hline 19335 & Megatherioidea indet. & Fragment of humeral diaphysis \\
\hline 19336 & Megatherioidea indet. & Distal tibia, incomplete astragalus, phalanx and ungual phalanx \\
\hline 19337 & Xyophorus atlanticus & $\begin{array}{l}\text { Partial left and right dentaries. Left dentary preserving } m f 1-m f 3 \text { completely; right dentary preserving } m f 2-m f 3 \\
\text { completely, } m f 1 \text { partially. Some postcranial elements: femur, ulna, astragalus }\end{array}$ \\
\hline 19338 & Megatherioidea indet. & Petrosal and several postcranial elements, including trapezium + metacarpal I \\
\hline 19339 & Hapalops sp. & Right tibia and astragalus \\
\hline 19340 & cf. Hapalops & $\begin{array}{l}\text { Anterior fragment of mandible, with cf } 1 \text { and mf1 broken, and an isolated molariform. } \\
\text { Astragalus, three metapodials and three ungual phalanges }\end{array}$ \\
\hline 19341 & Megatherioidea indet. & Postcranial elements \\
\hline
\end{tabular}


Appendix 1 - Continued

Segundas Barrancas Blancas (Estancias Cordón Alto and El Tordillo)

\begin{tabular}{|c|c|c|}
\hline MPM-PV & Taxa & Description \\
\hline 19342 & Megatherioidea indet. & Ungual phalanx \\
\hline 19343 & Megatheriidae indet. & Isolated large-sized teeth \\
\hline 19344 & Megatherioidea indet. & Ungual phalanges \\
\hline 19345 & Megatheriidae indet & Ungual phalanges and several fragmentary postcranial remains of a large-sized sloth \\
\hline 19346 & Megatherioidea indet. & Very fragmented mandible, with few teeth \\
\hline 19347 & Megatherioidea indet. & Caniniform teeth \\
\hline 19348 & Megatherioidea indet. & Partial mandible with two teeth, and proximal portion of an ungual phalanx \\
\hline 19349 & Megatherioidea indet. & Radius and ungual phalanx \\
\hline 19350 & Megatherioidea indet. & Isolated teeth (molariforms) \\
\hline 19351 & Megatherioidea indet. & $\begin{array}{l}\text { Several teeth, two ungual phalanges (one very large), fragment of left maxilla with the last three teeth. } \\
\text { Not associated, different individuals }\end{array}$ \\
\hline 19352 & Hapalops $c f$ elongatus & Portion of right dentary preserving cf1-mf3, with cf1 broken above level of alveolar margin \\
\hline 19353 & Hapalops cf. elongatus & $\begin{array}{l}\text { Partial skull, with palate and teeth; several postcranial elements (humerus, radius, proximal ulna, vertebrae, ribs, } \\
\text { manus and pes elements, among others. Same individual }\end{array}$ \\
\hline 19354 & Megatherioidea indet. & Two tooth fragments \\
\hline 19355 & $\begin{array}{l}\text { Nematheriinae? } \\
\text { Planopinae? }\end{array}$ & Ungual phalanx and distal fibula \\
\hline 19356 & Megatherioidea indet. & $\begin{array}{l}\text { Mandibular fragment, teeth fragments and postcrania: fragments of femora, distal tibiae, both patellas, proximal } \\
\text { and distal humeri, proximal ulna, proximal and distal radii, carpal/tarsal bones, ungual phalanges }\end{array}$ \\
\hline 19357 & Megatherioidea indet. & calcaneum and ungual phalanx fragments \\
\hline 19358 & Planopinae indet. & Distal tibia, proximal and distal humerus, femoral fragments, digit \\
\hline 19359 & $\begin{array}{l}\text { Planopinae? } \\
\text { Nematheriinae? }\end{array}$ & Several podial elements \\
\hline 19360 & Megatherioidea indet. & Maxillary fragment with broken Mf1-3 \\
\hline 19361 & Megatherioidea indet. & Mandibular fragment, very poorly preserved \\
\hline 19362 & Megatherioidea indet. & Digits and ungual phalanx \\
\hline 19363 & Megatherioidea indet. & Two tooth fragments \\
\hline 19364 & Megatherioidea indet. & Left astragalus \\
\hline 19365 & Megatherioidea indet. & Right astragalus \\
\hline 19366 & Megatherioidea indet. & Left astragalus \\
\hline 19367 & Megatherioidea indet. & Two phalanges \\
\hline 19368 & Megatherioidea indet & Tooth fragment \\
\hline 19369 & Megatherioidea indet & Postcrania fragmentary \\
\hline 19370 & Megatherioidea indet & Teeth and postcranial elements \\
\hline 19371 & Megatherioidea indet & Two astragali, associated \\
\hline
\end{tabular}




\section{APPENDIX 2 - List of the specimens of Folivora studied}

Megatherioidea

AMNH 9222, Hapalops rectangularis. Locality: Río Gallegos, Santa Cruz, Argentina. Stratigraphy: Santa Cruz Formation Collector: AMNH expedition 1899 AMNH 9250, H. ruetimeyeri. Locality: Río Gallegos, Santa Cruz, Argentina. Stratigraphy: Santa Cruz Formation. Collector: Brown

AMNH 9293, H. ruetimeyeri? Locality: Halliday Estancia, Santa Cruz, Argentina. Stratigraphy: Santa Cruz Formation. Collector: AMNH expedition 1899 MACN-A 6445-6470, Schismotherium fractum, neotype (Racco et al., 2018). Locality: La Cueva, Santa Cruz, Argentina. Stratigraphy: Santa Cruz Formation. Collector: C. Ameghino

MACN-A 2089-2092, Hapalops rectangularis, identified as the type in MACN catalogue (see text). Locality: Santa Cruz, Argentina. Stratigraphy: Santa Cruz Formation. Collector: C. Ameghino 1889-1890

MACN-A 4630, Xyophorus atlanticus. Locality: Río Sehuen, Santa Cruz, Argentina. Stratigraphy: Santa Cruz Formation, Santacrucian. Collector: C. Ameghino, 1890-91

MACN-A 4631, X. atlanticus, holotype. Locality: Corriguen Kaik, Santa Cruz, Argentina. Stratigraphy: Santa Cruz Formation, Santacrucian. Collector: C. Ameghino, 1890-91

MACN-A 6435, X. atlanticus. Locality: Corriguen Kaik, Santa Cruz, Argentina. Stratigraphy: Santa Cruz Formation, Santacrucian. Collector: C. Ameghino, 1890-91

MACN-A 4629, X. sulcatus, identified as the type in MACN catalogue (see text). Locality: Monte Observación, Santa Cruz, Argentina. Stratigraphy: Santa Cruz Formation, Santacrucian. Collector: Ameghino 1890-91

MACN-A 4632, X. sulcatus. Locality: Monte Observación, Santa Cruz, Argentina. Stratigraphy: Santa Cruz Formation, Santacrucian. Collector: Ameghino 1890-91

MACN-A 4633, X. sulcatus. Locality: Monte Observación, Santa Cruz, Argentina. Stratigraphy: Santa Cruz Formation, Santacrucian. Collector: Ameghino 1890-91

MACN-A 4634, X. andinus, holotype. Locality: Río Sehuen, Santa Cruz, Argentina. Stratigraphy: Santa Cruz Formation, Santacrucian. Collector: C. Ameghino, 1890-91

MACN-A 6417-18, X. simus, identified as the type in MACN catalogue (see text). Locality: La Cueva, Santa Cruz, Argentina. Stratigraphy: Santa Cruz Formation, Santacrucian. Collector: C. Ameghino 1892-93

MACN-A 4636, X. simus, identified as the type in MACN catalogue (see text). Locality: Monte Observación, Santa Cruz, Argentina. Stratigraphy: Santa Cruz Formation, Santacrucian. Collector: Ameghino 1890-91

MACN-A 6436, X. crassissimus. Locality: Corriguen Kaik, Santa Cruz, Argentina. Stratigraphy: Santa Cruz Formation, Santacrucian. Collector: C. Ameghino, 1892-93

MACN-A 2097, Trematherium intermixtum. Locality: Santa Cruz, Argentina. Stratigraphy: Santa Cruz Formation, Santacrucian. Collector: C. Ameghino, 1899-90

FMNH 13137, Schismotherium fractum. Locality: Killik Aike, Río Gallegos, Santa Cruz, Argentina. Stratigraphy: Santa Cruz Formation YPM-VPPU 15110, Hapalops indfferens. Locality: 10 miles south of Coy Inlet, Santa Cruz, Argentina. Stratigraphy: Santa Cruz Formation. Collector: J.B. Hatcher YPM-VPPU 15011, H. elongatus. Locality: Guer Aike Department, Santa Cruz, Argentina. Stratigraphy: Santa Cruz Formation. Collector: O.A. Peterson YPM-VPPU 15155, H. elongatus. Locality: 10 miles south of Coy Inlet, Santa Cruz, Argentina. Stratigraphy: Santa Cruz Formation. Collector: O.A. Peterson YPM-VPPU 15160, H. elongatus. Locality: 10 miles south of Coy Inlet, Santa Cruz, Argentina. Stratigraphy: Santa Cruz Formation. Collector: J.B. Hatcher YPM-VPPU15545, H. elongatus. Locality: Guer Aike Department, Santa Cruz, Argentina. Stratigraphy: Santa Cruz Formation. Collector: J. B. Hatcher YPM-VPPU 15597, H. elongatus. Locality: Killik Aike (Felton's Estancia), Santa Cruz, Argentina. Stratigraphy: Santa Cruz Formation. Collector: J.B. Hatcher YPM-VPPU 15531, H. elongatus. Locality: Killik Aike, Santa Cruz, Argentina Stratigraphy: Santa Cruz Formation. Collector: O.A. Peterson 1899 YPM-VPPU 15523, H. longiceps, holotype. Locality: 8 miles South of Coy Inlet, Santa Cruz, Argentina. Stratigraphy: Santa Cruz Formation. Collector: O.A. Peterson 1896-97

YPM-VPPU 15564, H. platycephalus, holotype. Locality: Lago Pueyrredón, Santa Cruz, Argentina. Stratigraphy: Santa Cruz Formation. Collector: J. B. Hatcher, 1899

YPM-VPPU 15520, H. ponderosus, holotype. Locality: Guer Aike Department, Santa Cruz, Argentina. Stratigraphy: Santa Cruz Formation. Collector: J. Hatcher

YPM-VPPU 15561, Analcimorphus giganteus. Locality: Guer Aike Department, Santa Cruz, Argentina. Stratigraphy: Santa Cruz Formation. Collector: O. Peterson

YPM-VPPU 15342, Xyophorus rostratus. Locality: Coy Inlet, Santa Cruz, Argentina. Stratigraphy: Santa Cruz Formation. Collector: J.B. Hatcher and O. Peterson

Megalonychidae

MACN-A 1061, Eucholoeops infernalis. Locality: Santa Cruz, Argentina. Stratigraphy: Santa Cruz Formation, Santacrucian. Collector: C. Ameghino MACN-A 2095, E. infernalis, identified as the type in MACN catalogue (see text). Locality: Corriguen-Kaik, Santa Cruz, Argentina. Stratigraphy: Santa Cruz Formation, Santacrucian. Collector: C. Ameghino 1890-91

MPM-PV 3401, E. ingens, neotype. Locality: Puesto Ea. La Costa, Santa Cruz, Argentina. Stratigraphy: Santa Cruz Formation, Santacrucian. Fossiliferous level: 7.2. Collector: MLP-Duke expeditions 2003 


\section{APPEndix 2 - Continued}

\section{Mylodontidae, Nematheriinae}

MACN-A 4660, Nematherium longirostris, type. Locality: Monte Observación, Santa Cruz, Argentina. Stratigraphy: Santa Cruz Formation, Santacrucian. Collector: Ameghino 1890-91

YPM-VPPU 15965, Nematherium sp. Locality: Coy Inlet, Santa Cruz, Argentina. Stratigraphy: Santa Cruz Formation. Collector: J.B. Hatcher and O.A. Peterson YPM-VPPU 15374, Nematherium? sp. Locality: Killik Aike, Santa Cruz, Argentina. Stratigraphy: Santa Cruz Formation. Collector: O.A. Peterson

Megatheriidae, Planopinae

MACN-A 4637, Planops longirostratus, identified as the type in MACN catalogue (see text). Locality: Killik Aike, Santa Cruz, Argentina. Stratigraphy: Santa Cruz Formation, Santacrucian. Collector: Ameghino 1890-91

MACN-A 4691-4694, Prepotherium potens, holotype. Locality: Río Sehuen, Santa Cruz, Argentina. Stratigraphy: Santa Cruz Formation, Santacrucian. Collector: C. Ameghino

MLP 97-XI-3-1, Prepoplanops boleadorensis, holotype. Locality; Cerro Boleadoras, Santa Cruz, Argentina. Stratigraphy: Cerro Boleadoras Formation, Grupo Zeballos, Early Miocene

NHMUK PV M 43404, Planops martini, holotype. Locality: Cabo Buen Tiempo, Santa Cruz, Argentina. Stratigraphy: Santa Cruz Formation, Santacrucian. Collector: H.T. Martin 1905

YPM-VPPU 15345, Prepotherium potens. Locality: Killik Aike, Santa Cruz, Argentina. Stratigraphy: Santa Cruz Formation, Santacrucian. Collector: O.A. Peterson, 1899 